\title{
Identification of protein secretion systems and novel secreted proteins in Rhizobium leguminosarum bv. viciae Martin Krehenbrink ${ }^{1,2}$ and J Allan Downie*1
}

Address: ${ }^{1}$ Department of Molecular Microbiology, John Innes Centre, Norwich Research Park, Colney Lane, Norwich NR4 7UH, UK and ${ }^{2}$ Current address: Unité de Génétique Moléculaire, Institut Pasteur 25, rue du Dr. Roux, 75724 Paris Cedex 15, France

Email: Martin Krehenbrink - mkrehen@pasteur.fr; J Allan Downie* - allan.downie@bbsrc.ac.uk

* Corresponding author

Published: 29 January 2008

BMC Genomics 2008, 9:55 doi:10.1/86/|47|-2/64-9-55
Received: 6 September 2007

Accepted: 29 january 2008

This article is available from: http://www.biomedcentral.com/147I-2/64/9/55

(C) 2008 Krehenbrink and Downie; licensee BioMed Central Ltd.

This is an Open Access article distributed under the terms of the Creative Commons Attribution License (http://creativecommons.org/licenses/by/2.0), which permits unrestricted use, distribution, and reproduction in any medium, provided the original work is properly cited.

\begin{abstract}
Background: Proteins secreted by bacteria play an important role in infection of eukaryotic hosts. Rhizobia infect the roots of leguminous plants and establish a mutually beneficial symbiosis. Proteins secreted during the infection process by some rhizobial strains can influence infection and modify the plant defence signalling pathways. The aim of this study was to systematically analyse protein secretion in the recently sequenced strain Rhizobium leguminosarum bv. viciae 384I.

Results: Similarity searches using defined protein secretion systems from other Gram-negative bacteria as query sequences revealed that $R$. I. bv. viciae 384 I has ten putative protein secretion systems. These are the general export pathway (GEP), a twin-arginine translocase (TAT) secretion system, four separate Type I systems, one putative Type IV system and three Type V autotransporters. Mutations in genes encoding each of these (except the GEP) were generated, but only mutations affecting the PrsDE (Type I) and TAT systems were observed to affect the growth phenotype and the profile of proteins in the culture supernatant. Bioinformatic analysis and mass fingerprinting of tryptic fragments of culture supernatant proteins identified 14 putative Type I substrates, 12 of which are secreted via the PrsDE, secretion system. The TAT mutant was defective for the symbiosis, forming nodules incapable of nitrogen fixation.

Conclusion: None of the R. I. bv. viciae 384I protein secretion systems putatively involved in the secretion of proteins to the extracellular space (Type I, Type IV, Type V) is required for establishing the symbiosis with legumes. The PrsDE (Type I) system was shown to be the major route of protein secretion in non-symbiotic cells and to secrete proteins of widely varied size and predicted function. This is in contrast to many Type I systems from other bacteria, which typically secrete specific substrates encoded by genes often localised in close proximity to the genes encoding the secretion system itself.
\end{abstract}

\section{Background}

Rhizobium leguminosarum bv. viciae is a Gram-negative soil bacterium which forms a mutualistic symbiosis with legumes, resulting in nitrogen-fixing root nodules. This symbiotic relationship is initiated by an exchange of signals between the two partners. While the general features of this signal exchange are common to all rhizobia-plant symbioses, differences in the signalling molecules allow only certain bacterium-plant combinations to lead to a successful symbiosis. Plant-made flavonoids released into 
the rhizosphere $[1,2]$ induce rhizobia to make specific signalling molecules known as Nod factors, which are four or five $\beta-1,4$ linked $N$-acetyl-glucosamine residues with a fatty acid residue replacing the $N$-acetyl group at the nonreducing end. This basic structure can carry various substituents (such as acetyl, methyl, carbamoyl, sulfuryl and various glycosyl groups) depending on the rhizobial strain, and many strains synthesise a limited variety of Nod factors $[3,4]$.

In addition to Nod factors, secreted proteins can contribute to nodulation ability. NodO is a protein secreted via a Type I secretion system (PrsDE) by some rhizobia and heterologous expression of nodO could extend the host range of some rhizobial strains $[5,6]$. Type I secretion systems transport proteins from the cytoplasm across both membranes to the extracellular space and are usually composed of three gene products: an ATPase of the ATPbinding cassette $(\mathrm{ABC})$ protein family; a membrane fusion protein which spans the periplasm and links the inner and outer membranes [7]; and an outer membrane protein [8]. Their substrate proteins usually carry tandem nonapeptide glycine-rich repeats known as RTX (repeat in toxin) motifs which form a $\beta$-roll structure stabilised by coordinated $\mathrm{Ca}^{2+}$ ions $[9,10]$. In $R$. leguminosarum and some other rhizobia, both glycanases involved in bacterial exopolysaccharide (EPS) processing and rhizobial adhesion proteins are secreted via a Type I secretion system (PrsDE) in addition to NodO [6,11-16]. Secreted cell-wall degrading enzymes may help to erode plant cell walls enhancing infection and in Rhizobium leguminosarum biovars trifolii and viciae, cell-associated pectinolytic and cellulolytic enzymes have been found $[12,13,17]$. Sinorhizobium meliloti has been reported to induce the production of polygalacturonase in alfalfa roots [18].

Other rhizobia make use of Type III and Type IV protein secretion systems to inject effector proteins directly into the host plant cells where they modify plant signalling pathways [19-22]. Type III secretion systems translocate proteins across both membranes using ATP. They are assembled from over 20 proteins, many of which closely resemble proteins involved in flagellar biogenesis $[23,24]$. In some cases, the flagellar apparatus has been shown to export proteins not related to the flagellum [25]. The proteins are normally delivered into the eukaryotic cytoplasm, where they then alter the host metabolism to suit the bacterial needs [26]. In Rhizobium sp. NGR234 several proteins including NopX, NopA, NopB, NopP and NopL, were shown to be secreted via a Type III system upon flavonoid induction [21,27-29].

The Vir system of Agrobacterium tumefaciens is a wellknown Type IV secretion system involved in the transfer of DNA and protein to the plant cell. The Type IV secretory machinery is encoded by the virB1-11 genes [30]. A related system in Mesorhizobium loti delivers effector proteins into plants during nodule initiation [20].

The twin arginine translocase pathway (TAT) pathway exports folded proteins [31,32] often with posttranslational modifications [31,33-35] and does not recognise unfolded proteins [36]. TAT substrates carry an N-terminal tripartite signal sequence similar to that of GEP substrates, except that the signal peptide is usually longer and carries two consecutive arginine residues near the $\mathrm{N}$-terminus $[33,37]$. Inactivation of this protein secretion system in R. l. bv viciae UPM791 led to the inability of the rhizobia to progress beyond the infection zone and the formation of nodules that were unable to fix nitrogen [38].

Several types of protein secretion system function in Gram-negative bacteria, but have not been studied in rhizobia with regard to nodulation. The general export pathway (GEP) is the main pathway for the secretion of proteins to the periplasm in most bacteria. An N-terminal signal peptide which is cleaved from the exported protein by a specific signal peptidase [39]. In E. coli, the GEP is composed of a complex of SecD, SecE, SecF, SecG and $\mathrm{SecY}$ in the cytoplasmic membrane. In the cytoplasm SecB keeps proteins destined for secretion in an unfolded state [40] and SecA binds to the signal peptide and uses ATP to drive protein export through the SecYEG channel [41-43].

Type II secretion systems translocate proteins from the periplasm and are thus dependent on the GEP or TAT pathways $[44,45]$. Their substrates consist of folded proteins, and between 12 and 15 different proteins are involved in Type II secretion, many of them sharing features with the Type IV pilus biogenesis system [46].

In Type $\mathrm{V}$ secretion systems (also termed autotransporters), the secreted protein transports itself across the outer membrane after being transported to the periplasm by the GEP. Autotransporters have a GEP signal peptide, a variable passenger domain and a C-terminal $\beta$-domain, which forms a pore in the outer membrane through which the passenger domain passes. The passenger domain is then released by a peptolytic activity or remains covalently bound to the $\beta$-domain [47]. Many autotransporter proteins have an unusually long $\mathrm{N}$-terminal signal peptide of more than 42 amino acid residues $[47,48]$. The so-called unlinked autotransporters or two-partner secretion (TPS) systems $[49,50]$ have separate passenger and $\beta$-domain proteins, each carrying a GEP signal peptide. Export of the passenger domain from the periplasm proceeds via an outer membrane pore formed by the $\beta$-domain. 
Fimbriae and Pili are not commonly regarded as protein secretion systems, but do transport the pilus or fimbrial subunit proteins across the outer membrane. The subunit proteins are usually exported to the periplasm by the GEP, and some proteins involved in pilus biosynthesis display similarity to components of the Type II protein secretion machinery. In Pap fimbriae, the fimbrial usher proteins mediate the assembly of the fimbrial subunits and also form a pore through which the fimbriae pass through the outer membrane.

MscL and holin both form channels within the inner membrane through which proteins can pass under certain conditions. Holins are often phage-derived and facilitate the export of autolysin proteins leading to the degradation of the cell wall and death. The pores formed by MscL only open during severe hypoosmotic shock and are though to be primarily involved in rapidly relieving excessive turgor by allowing low- to medium-molecular weight osmolytes to diffuse out of the cell. The channels do however also open wide enough to allow the escape of small proteins such as thioredoxin into the periplasm $[51,52]$.

In this study, the genome of $R$. $l$. bv. viciae 3841 was analysed for the presence of known protein secretion systems to assess their role in the nodulation process.

\section{Results}

Identification of genes encoding different protein transport systems

a) Identification of general export pathway (GEP) genes

The components of the GEP from Escherichia coli were used as query sequences to search the R. l. bv. viciae 3841 genome database using the BLASTP algorithm [53]. R. $l$. bv. viciae 3841 was found to carry single genes coding for SecA (RL4298), SecB (RL0006), SecD (RL0680), SecE (RL1759), SecF (RL2055), SecG (RL2512) and SecY (RL1794), which suffice to constitute a functioning GEP machinery (Table 1). These chromosomal genes were not located in operons or even close to one another. Only one copy of each of the genes encoding type I (RL1510) and type II (RL0410) signal peptidases were found in the $R . l$. bv. viciae 3841 genome.

\section{b) The tat $A B C$ genes of the twin-arginine translocation pathway} (TAT)

To search for components of the TAT machinery, the sequences of TatA, TatB, TatC and TatE from E. coli were used as queries. No copy of tatE was found, but tatA (RL2046), tatB (RL2047) and tatC (RL2048) appeared to be located within one operon. The same organisation is found A. tumefaciens [54] and R. l. bv. viciae UPM 791 [38] and in the published genome sequences of other rhizobia such as R. etli CFN 42 [55] and S. meliloti 1021 [56]. c) Identification of genes encoding four predicted Type I protein secretion systems

The prsDE genes encode a typical Type I secretion system in rhizobia [12]. Using PrsD and PrsE as queries, three novel putative Type I systems were identified in addition to PrsDE. As the search was expected to return many putative $\mathrm{ABC}$ transporters not related to protein secretion [57], the 11 closest hits to the PrsD sequence were queried against the R. $l$. bv. viciae 3841 genome and pooled with the 11 closest hits for each query to give a subset of 16 unique putative protein sequences (most of the $11 \times 11=$ 121 sequences were repeat hits within the sets of 11). These 16 sequences were then queried against the NCBI database using BLASTP [53]. This revealed that (a) three sequences (including PrsD) were most similar to protein transporters of the AprD-type (alkaline protease) from Pseudomonas sp., (b) one was most similar to bacteriocin/ lantibiotic transporters (SunT-type), and (c) the rest were most similar to $\mathrm{ABC}$ drug/metabolite transporters and polysaccharide exporters. A radial tree (Fig. 1) shows the relationships of the 16 identified $\mathrm{ABC}$ proteins. The four $\mathrm{ABC}$ proteins predicted to be involved in protein secretion all contained a conserved ATP-binding Walker A region (GXXGXGKT/S) [58] and are the PrsDE system, two predicted PrsDE-like systems encoded by genes we have named the toaDE (RL0072 and RL0071) and tobDE (RL0623 and RL0622) genes and the bltDE genes (pRL90164 and pRL90165) encoding putative proteins with similarity to bacteriocin/lantibiotic exporters. The other proteins with the highest similarity to ABC drug/ metabolite transporters and polysaccharide exporters are thought to be involved in the transport of small molecules or polysaccharides rather than proteins.

\section{d) Identification of predicted Type I substrates}

Genes encoding Type I substrates are often close to the genes encoding Type I secretion systems. The prs $D E$ genes are preceded by plyA encoding the cell-bound glycanase PlyA, a known substrate of the PrsDE system $[13,59]$. None of the genes within $10 \mathrm{~kb}$ of the toaDE (RL0072/ RL0071) or tobDE (RL0623/RL0624) encodes proteins which are known Type I substrates.

Proteins secreted by Type I secretion systems often contain repeated acidic RTX (repeat in toxin) motifs probably involved in protein folding in the extracellular space $[10,60]$. The known Type I proteins with RTX domains, NodO from R. l. bv. viciae 8401/pRL1 [GenPept:P15728], HlyA from E. coli O157:H7 [GenPept:AAA20544], and LipA from Serratia marcescens [GenPept: BAA02519], were used as to search the R. l. bv. viciae 3841 database using BLASTP. The resulting 15 highest-scoring proteins were each used to search the non-redundant NCBI database for similar proteins (the 15 highest-scoring proteins were chosen as a cut-off instead of a defined expect-value to 
Table I: Homologs of known protein secretion systems identified in the genome of R. I. bv. viciae $384 \mathrm{I}$.

\begin{tabular}{|c|c|c|c|c|}
\hline System & Homolog I & Homolog II & Homolog III & Homolog IV \\
\hline \multicolumn{5}{|l|}{ a) General export pathway } \\
\hline SecB & RL0006 & & & \\
\hline SPase II & RL04IO & & & \\
\hline YidC & RL0453 & & & \\
\hline $\operatorname{Sec} D$ & RL0680 & & & \\
\hline SPase I & RLI5IO & & & \\
\hline SecE & RLI759 & & & \\
\hline $\operatorname{Sec} Y$ & RLI794 & & & \\
\hline SecF & RL2055 & & & \\
\hline SecG & RL25I 2 & & & \\
\hline $\operatorname{Sec} A$ & RL4298 & & & \\
\hline Fts Y & RL4543 & & & \\
\hline $\mathrm{Ffh}$ & RL4547 & & & \\
\hline \multicolumn{5}{|l|}{ b) Twin arginine pathway } \\
\hline TatA & RL2046 & & & \\
\hline TatB & RL2047 & & & \\
\hline TatC & RL2048 & & & \\
\hline \multicolumn{5}{|l|}{ c) Type I pathway } \\
\hline AprE & RL3657 & RL007I & RL0622 & pRL90I65 \\
\hline AprD & RL3658 & RL0072 & RL0623 & pRL90I64 \\
\hline TolC & none & & & \\
\hline \multicolumn{5}{|l|}{ d) Type II pathway } \\
\hline Any component & none & & & \\
\hline \multicolumn{5}{|l|}{ e) Type III/flagellar pathway } \\
\hline FliF & RL0695 & & & \\
\hline FlhB & RL0699 & & & \\
\hline $\mathrm{FliG}$ & RL0700 & & & \\
\hline $\mathrm{FliN}$ & RL070I & & & \\
\hline FliM & RL0702 & & & \\
\hline Flil & RL0705 & & & \\
\hline $\mathrm{Flgl}$ & RL07I 2 & & & \\
\hline $\mathrm{FlgH}$ & RL07I4 & & & \\
\hline FliL & RL07I 5 & & & \\
\hline FliP & RL07I 6 & & & \\
\hline FliQ & RL0734 & & & \\
\hline FlhA & RL0735 & & & \\
\hline FliR & RL0736 & & & \\
\hline \multicolumn{5}{|l|}{ f) Type IV pathway } \\
\hline VirBI & pRL70I49 & & & \\
\hline VirB2 & PRL70I50 & & & \\
\hline VirB3 & PRL70I5। & & & \\
\hline VirB4 & PRL70I52 & & & \\
\hline VirB5 & PRL70I53 & & & \\
\hline VirB6 & PRL70I54 & & & \\
\hline VirB8 & pRL70I55 & & & \\
\hline VirB9 & PRL70I56 & & & \\
\hline VirB।O & PRL70I57 & & & \\
\hline VirBII & PRL70I58 & & & \\
\hline \multicolumn{5}{|l|}{ g) Type V pathway } \\
\hline AT & RLI927 & RLII96 & RLI069 & \\
\hline TPS & None & & & \\
\hline \multicolumn{5}{|l|}{ h) Holins } \\
\hline Holin & None & & & \\
\hline \multicolumn{5}{|c|}{ i) Large conductance mechanosensitive channel } \\
\hline MscL & RL0602 & & & \\
\hline \multicolumn{5}{|l|}{ i) Pilus } \\
\hline PilQ & RL02। 0 & & & \\
\hline PilA & RL02II & & & \\
\hline CpaA & RL0212 & & & \\
\hline
\end{tabular}


Table I: Homologs of known protein secretion systems identified in the genome of $R$. I. bv. viciae 384I. (Continued)

$\begin{array}{cl}\text { CpaB } & \text { RL0213 } \\ \text { CpaC } & \text { RL0214 } \\ \text { CpaD } & \text { RL0215 } \\ \text { CpaE } & \text { RL0216 } \\ \text { CpaF } & \text { RL0217 } \\ \text { TadB } & \text { RL0218 } \\ \text { TadC } & \text { RL0219 } \\ \text { k) Fimbrial usher protein } & \text { none }\end{array}$

accommodate for proteins of varying lengths). If the highest similarity was to a known non-substrate, the protein was added to a list of false positives. Proteins with high similarity to known secreted proteins were listed as possible true positives. Any new proteins from $R$ l. bv. viciae 3841 identified as possible Type I substrates were re-tested as query sequences for the $R l$. bv. viciae 3841 genome and the whole process reiterated until it converged on a defined set of sequences. Every protein sequence within the set could be used as an initial query to return all members of the set. These sequences were additionally analysed for the presence of repeat sequences using the DOTTER software [61].

Using this approach, 14 different proteins predicted to be secreted by a Type I secretion system were identified. Seven were already known to be secreted via the PrsDE system in R. leguminosarum or were very similar to known

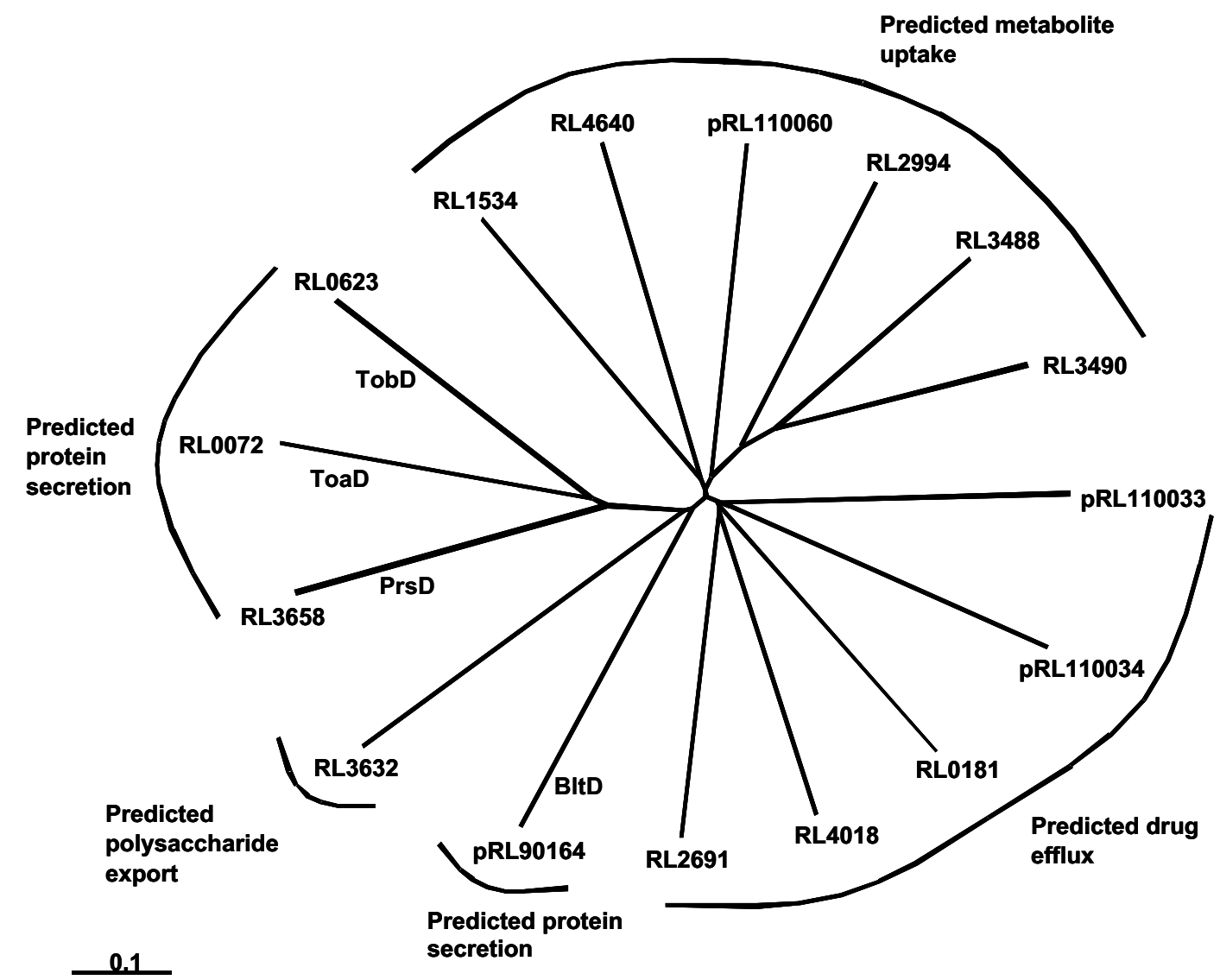

Figure I

Unrooted dendrogram of R. I. bv viciae 384 I proteins with similarity to PrsD. The bar represents 0.1 amino acid changes; predicted functions for proteins are given. 
substrates $[12,13,62]$. Of these seven, three were rhizobial adhering proteins (RapA2, RapB and RapC), two were predicted glycanases (PlyA and PlyB), one was the nodulation protein NodO, and one (RL3023) was 63\% identical to PlyB and so was named PlyC.

The sequence motif structures of the other seven predicted Type I secretion substrates are summarised in Fig. 2, including NodO for comparison. Of these RL0790 was by far the most strongly predicted new Type I substrate. While the N-terminal 250 amino acid residues had similarity (32\% identity) to the Zn-dependent metalloprotease PrtA from Pseudomonas fluorescens SIK W1

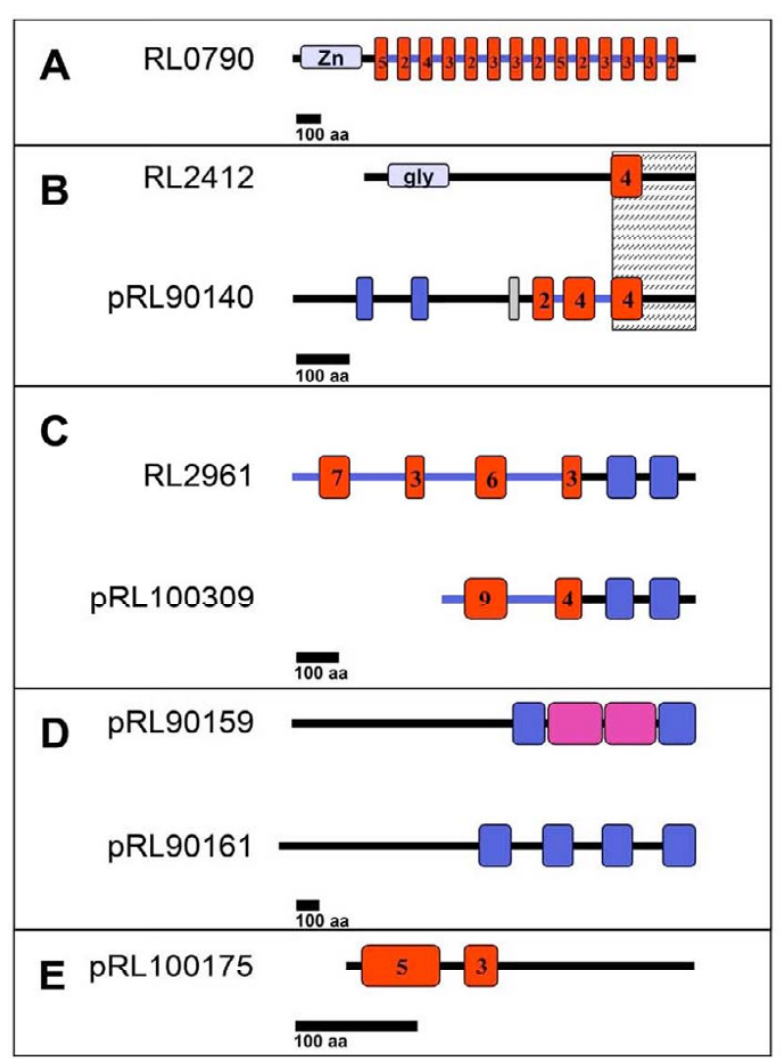

\section{Figure 2}

Domains found in proteins prediced to be secreted via a Type I system. Coloured elements represent repeated sequences. Red denotes clusters of repeated RTX nonapeptides; the numbers of repeats are indicated. $A: Z n$, Zn-metalloprotease domain. B: Blue boxes represent single repeated domains; gly, glycosyl hydrolase domain; dark grey, TPT repeat; hatched area marks sequence similarity. C: Blue boxes represent single cadherin domains. D:. Blue, repeated sequence I; magenta, repeated sequence 2. E: NodO protein shown for comparison. Bar represents 100 amino acid residues.
[GenPept:AAD09851], most of the protein was made up of an extensive RTX motif region carrying a total of 80 nonapeptide motifs occuring in 14 clusters of 2-5 units repeated roughly every 40 amino acids (Fig. 2A). These 40 amino acids constitute a repeated domain that occurs 13 times. The $\sim 50 \mathrm{C}$-terminal residues are not part of a repeat.

RL2412 and pRL90140 were very similar (76\% identity) in their last 150 amino acid residues, but completely different in the rest of their sequences (Fig. 2B). RL2412 carries one region of four consecutive RTX motifs towards the C-terminus and has limited similarity to glycosyl hydrolases in the N-terminal region (CD-score 31 bits (70) in conserved domain database RPSBLAST search). In pRL90140, there are three RTX motif regions containing 2, 4 and 4 RTX motifs respectively. It contains the sequence Thr-Pro-Thr repeated in tandem six times (TPT TPT TPT TPT TPT TPT) just in front of the first RTX region. The $\mathrm{N}$ terminus contains two copies of a 32 amino acid sequence ( $41 \%$ identity to each other) that resembles repeats in cyanobacterial parallel beta-helix repeat proteins of unknown function $(56 \%$ and $53 \%$ identity to a protein from Anabaena variabilis ATCC 29413 [GenPept:YP_322399] for the first and second repeat, respectively).

RL2961 and pRL100309 (Fig. 2C) are similar, but differ in the number of RTX motifs towards the N-terminus (four in RL2961, two in pRL100309). Both contain putative calmodulin-like calcium-binding motifs repeated two times towards the C-terminus. Similar motifs are found in hypothetical proteins from other bacteria (e.g. amb3275 from Magnetospirillum magneticum AMB-1 [GenPept:YP_422638] and bll3714 from Bradyrhizobium japonicum USDA 110 [GenPept:BAC48979], 39\% identity in both) and also resemble cadherins, calcium-binding cellcell adhesion proteins from animal cells (35\% identity to mouse cadherin-10, [GenPept: AAH62962]). Cadherins are involved in mediating the formation of the adherens junction in animals in a calcium-dependent manner [63].

The genes encoding pRL90159 and pRL90161 are both located just upstream of the putative bacteriocin/lantibiotic transporter system bltDE. Both encode similar, very large proteins with predicted sizes of $179 \mathrm{kDa}$ and 184 $\mathrm{kDa}$, respectively. They lack a classical RTX domain, but do contain a repeated $\sim 140$ amino acid motif of unknown function. These motifs are repeated four times in the Cterminal half of pRL90161, two times in pRL90159 (Fig. 2D) and display 55-65\% identity to four similar repeats in a hypothetical protein from Nitrobacter hamburgensis X14 [GenPept:YP_578257]. In pRL90159, the second and third repeats are replaced by two copies of a 220 amino 
acid sequence ( $96 \%$ identity to each other) of unknown function (Fig. 2E).

\section{e) Type II and Type III protein secretion systems are absent, but a Type IV system may be present}

Although Type II secretion systems are common and widespread in many Gram-negative bacteria such as Pseudomonas spp. [64], no components of this pathway were found in R. l. bv. viciae 3841 using PulC-O from Klebsiella oxytoca as query sequences. The only proteins with similarity to components of Type III secretion systems were components of the flagellar apparatus.

Using the VirB1-11 proteins of A. tumefaciens as a query, two separate clusters of genes were found. The first is on the transmissible plasmid pRL8 and is very similar to other plasmid transfer systems (trb) implying that these genes are most likely to be involved in plasmid transfer, rather than protein secretion. The second cluster is on the transmissible plasmid pRL7 and contains putative virB1, virB2, virB3, virB4, virB5, virB6, virB8, virB9, virB10 and virB11 genes (pRL70149-pRL70158), thus possessing essential genes for DNA and/or protein transport via a Type IV secretion system [65]. The presence of this cluster does however not necessarily identify this cluster as a protein secretion system. As the process of type IV protein export is not yet well understood, it is not possible to tell from sequence data alone whether these components are involved in protein export or conjugal DNA transport.

\section{f) Identification of genes encoding Type $V$ systems}

Three putative proteins with sequence similarity to the autotransporter BrkA [GenPept:AAA51646] from Bordetella pertussis were identified from the R. l. bv. viciae 3841 genome (Table 1). The amino acid sequences of all three putative autotransporters included predicted $\mathrm{N}$-terminal signal peptides of 35 (AutA, RL1927), 41 (AutB, RL1196) and 29 (AutC, RL1069) amino acid residues as predicted by SignalP 3.0, Hidden Markov model [66]. While the $\beta$ domain was well conserved in all three cases, no significant similarity to any known or putative protein was found for the N-proximal passenger domain. No members of a two-partner secretion system were detected using the $\beta$-domains of BrkA and the identified putative autotransporters as query sequences.

The three predicted autotransporter proteins encoded by aut $A, a u t B$ and autC in different regions of the chromosome are large (1290, 875 and 1204 amino acid residues, respectively). The 300-450 C-terminal amino acid residues of each could be assigned to the autotransporter $\beta$ domain by similarity to the $\beta$-domains of known autotransporters including BrkA. As the $\beta$-domain of autotransporters is well conserved across species, it was omitted from BLASTP searches to avoid skewing the results towards proteins with unrelated passenger domains. The protein most similar to the passenger domain of AutA was a predicted autotransporter [GenPept:YP_296187] from Ralstonia eutropha JMP134 (36\% identity). AutB was most similar to a predicted autotransporter [GenPept:YP_673151] from Mesorhizobium sp. BNC1 (43\% identity). The protein most similar to the passenger domain of AutC was a putative autotransporter [GenPept:YP_485594] from Rhodopseudomonas palustris HaA2 (33\% identity). There was no significant similarity to the passenger domains of autotransporters from other rhizobia. The genetic neighbourhood of the genes also did not yield any direct indication to possible functions.

g) Identification of genes encoding fimbriae, pili, MscL channels and holins

Although no fibrial usher proteins were found, the R. $l$. bv. viciae 3841 genome contains a cluster of genes predicted to be involved in Cpa pilus biogenesis (Table 1). The R. $l$. bv. viciae 3841 genome was found to encode no holins and one putative MscL protein (RL0602).

\section{Phenotypes of mutants affected in predicted secretion systems}

To determine the functions of the identified putative protein secretion systems, we generated derivatives of strain 3841 carrying insertion mutations in prsD (A895), toaD (A913), tobD (A896), virB6 (A897), autA (A1010), autB (A1011), autC (A1012) and tatC (A1052). The mutants were tested for polygalacturonase (PGase) activity, glycanase activity, motility, biofilm formation and growth on different carbon sources (mannitol and succinate). All mutants were able to grow on TY, Y-succinate and Y-mannitol plates.

None of the mutants was affected in cell-associated PGase activity, suggesting that this activity is independent of the identified secretion systems. The prsD (A898) mutant lacked extracellular glycanase activity, failed to form biofilm rings in shaking culture, and produced very mucoid colonies and viscous culture supernatants (not shown). Such phenotypes were observed previously with a $\operatorname{prs} D$ mutant of $R$. $l$. bv. viciae strain A34 [12,59]. No such effects were observed with any of the other mutants including A913 (toaD), or A896 (tobD). To rule out the possibility of additive phenotypes or redundancy between the different Type I systems, we constructed a toaD/tobD/ prsD triple mutant (A912) and toaD/prsD (A911) and tobD/prsD (A903) double mutants, but all had the same phenotypes as A898 (prsD).

Whereas the wild type (and all the other mutants tested) swarmed outward from the point of inoculation on $0.2 \%$ agar TY plates, the tatC mutant (A1052) formed a tight colony and showed no sign of swarming behaviour. 
Growth of the tatC mutant in liquid TY medium was slightly impaired (it had a doubling time of $4.5 \mathrm{~h}$ compared with $3 \mathrm{~h}$ for WT and the other mutants). Microscopy revealed that the tat $C$ mutant was much more rounded in shape than the wild type.

\section{All mutants except Al052 (tatC) are capable of effective nodulation}

To examine the role of the identified secretion systems in nodulation, pea seedlings (cv. Frisson) were inoculated with wild type R. l. bv. viciae 3841, A895 (prsD), A913 (toaD), A896 (tobD), A897 (virB7), A1010 (autA), A1011 (autB), A1012 (autC) and A1052 (tatC). After three weeks growth on nitrogen-limited medium, the plants inoculated with the tatC mutant (A1052) looked nitrogen starved, and the nodules formed were unable to fix nitrogen based on measurements of acetylene reduction; staining of these nodules with SYTO 13 [67] revealed bacteria near the tip of the nodule, but they did not extend as far into the nodule as wild type bacteria (Fig. 3). All of the other mutants formed normal numbers of nitrogen-fixing nodules (data not shown). Nodulation experiments carried out with the alternative host plants broad bean (Vicia faba cv. The Sutton) and hairy vetch (Vicia hirsuta) mirrored the results obtained on pea plants.

\section{The tatC mutant has enhanced levels of proteins in the} culture supernatant but lacks flagellin

A comparison by SDS-PAGE of the proteins in the culture supernatant of the tatC mutant (A1052) and the wild type grown in Y-mannitol liquid medium showed clear differences in the protein pattern (Fig. 4). Although there were many bands in common, A1052 consistently contained more total protein in the culture supernatant as estimated by loading proteins precipitated from equal amounts of culture supernatant. The abundant proteins of around 36 $\mathrm{kDa}$ produced by the wild type but missing from the supernatant of A1052 (tatC) were identified by MALDIToF as flagellins (RL0718 and RL0720). Although the TAT pathway secretes proteins to the periplasm and not directly to the extracellular space, the absence of flagellar proteins from the culture supernatant of a tatC mutant was previously shown for A. tumefaciens [54].

Periplasmic proteins from R. l. bv. viciae 3841 and A1052 (tatC) were isolated by cold hypo-osmotic shock and analysed by gel electrophoresis. The absence of cytoplasmic contamination of the periplasmic protein preparation was checked by measuring glucose-6-phosphate dehydrogenase (G6PDH) activity [68]. Specific G6PDH activity in the periplasmic preparations was less than $4 \%$ of the specific G6PDH activity in whole cell extract. Although the TAT machinery exports proteins to the periplasm, there were no major differences in the periplasmic protein pro-
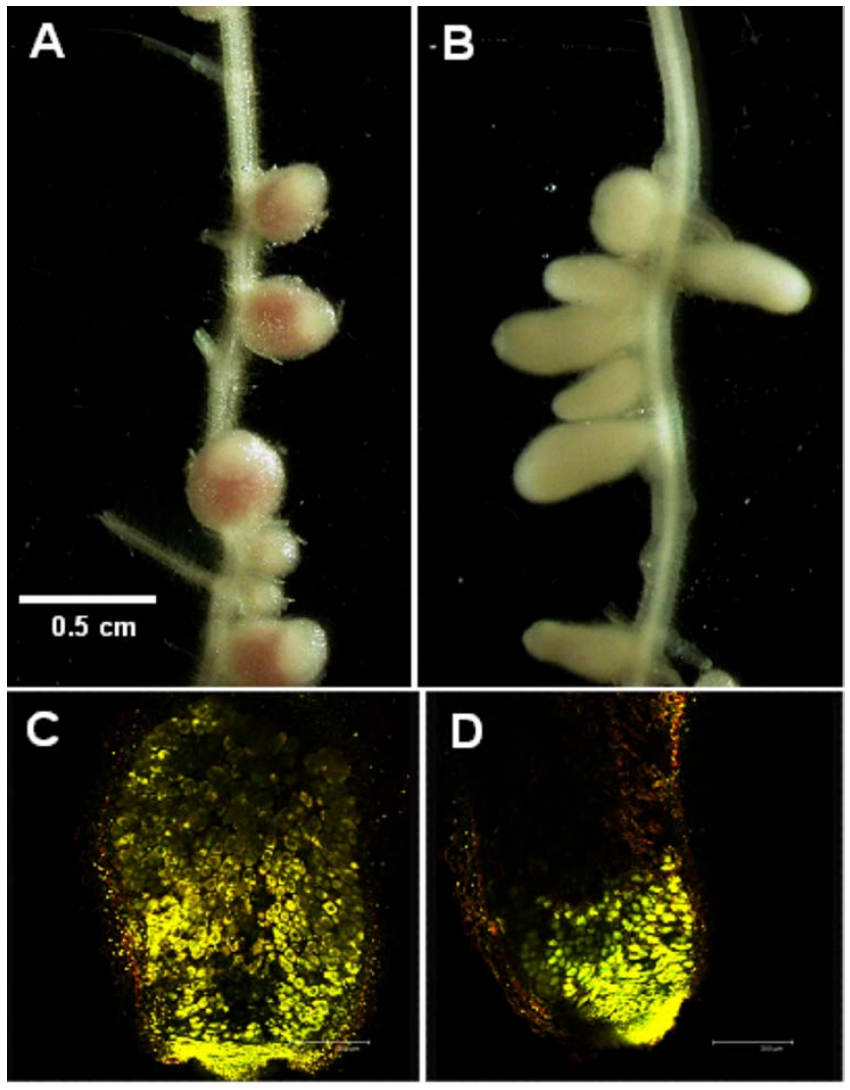

Figure 3

The $R$. I. bv. viciae 384 I tatC mutant exhibits anomalous infection of pea nodules. Nodules formed on pea plant roots (cv. Frisson) three weeks after inoculation with wild type $R$. I. bv. viciae 384 I (A, C) and the tatC mutant Al 052 (B, D). A and B are images of fresh nodules, $C$ and D were nodules preserved in $70 \%$ ethanol before staining with SYTO I 3 dye. Structures of high DNA content (bacteria and plant cell nuclei) are stained yellow. The nodule tip is at the bottom.

file of R. l. bv. viciae 3841 and the tatC mutant A1052 (Fig. 4.).

\section{Identification of proteins present in the culture supernatant of mutants in predicted protein secretion systems and the wild type}

Culture supernatant proteins of $R$. l. bv. viciae 3841 and the prsD (A895), toaD (A913), tobD (A896), virB6 (A897), autA (A1010), autB (A1011) and autC (A1012) mutants grown in Y-mannitol medium were analysed by SDSPAGE. Only the supernatant protein profile from the prs $D$ mutant (A895) differed from that of the wild type and was missing seven protein bands (Fig. 5). The seven proteins corresponding to the indicated bands in Fig. 5 were identified by MALDI-ToF MS fingerprinting (Table 2). Six of these were either known Type I substrates (PlyB and 

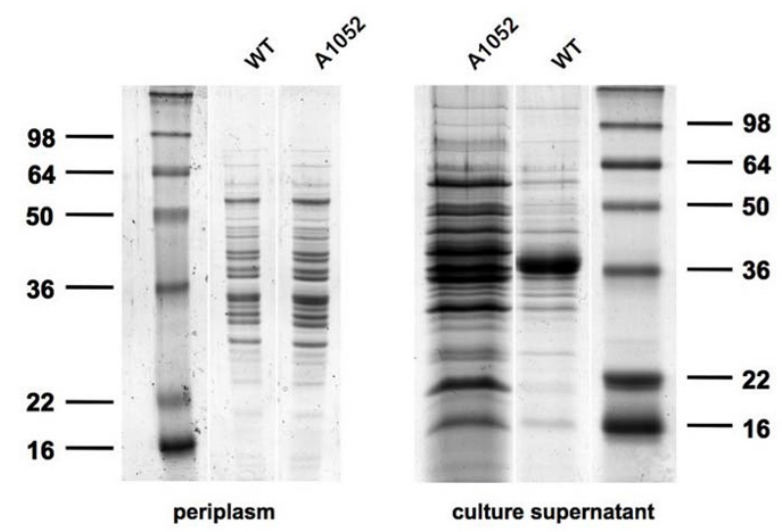

\section{Figure 4}

The tatC mutant of $R$. I. bv. viciae $384 I$ is altered in the culture supernatant protein profile, but is very similar to the wild type in its periplasmic protein profile. R. I. bv. viciae $384 \mathrm{I}$ and the tatC mutant (A 052) were grown for three days in $100 \mathrm{ml}$ TY (periplasm) or for four days in $100 \mathrm{ml} \mathrm{Y}$-mannitol medium (culture supernatant). Periplasmic proteins were prepared by cold hypo-osmotic shock, $\sim 30 \mu \mathrm{g}$ were loaded per lane. Culture supernatant proteins were precipitated with TCA and protein representing $20 \mathrm{ml}$ of culture were loaded in each lane.

RapA2) [62] or were predicted above (RL2961, pRL100309, pRL90140 and RL2412) to be secreted using bioinformatic analyses.

One of the proteins missing from the culture supernatant of the prsD mutant (A895) was a predicted nucleoside diphosphate kinase (NDK, RL1580). NDK is generally a cytoplasmic enzyme involved in nucleotide metabolism [69] and catalyses the general reaction $N_{x} T P+N_{y} D P \leftrightarrow$ $\mathrm{N}_{\mathrm{x}} \mathrm{DP}+\mathrm{N}_{\mathrm{y}} \mathrm{TP}$, where $\mathrm{N}_{\mathrm{x} \text { or } y}$ can be any base. Therefore, its presence in the supernatant of the wild type was unusual, although NDK has been shown to be secreted via a Type I system in $P$. aeruginosa [70]. The absence of NDK from the culture supernatant of A898 (prsD) indicates specific export by the PrsDE Type I system. To rule out cytoplasmic contamination of the culture supernatant, the small ( 22 $\mathrm{kDa}$ ) and highly expressed cytoplasmic protein RhiA was used as a marker. RhiA is a protein of unknown function $[71,72]$, and its high abundance and the availability of a specific antiserum [73] made it a good choice as a marker protein, because cell lysis would release large amounts of RhiA into the culture medium. RhiA could not be detected in the culture supernatant of bacteria grown for 4 days to mid-stationary phase (data not shown).

Double and triple mutants in toaD, tobD and prsD were made but no effects on supernatant proteins were seen

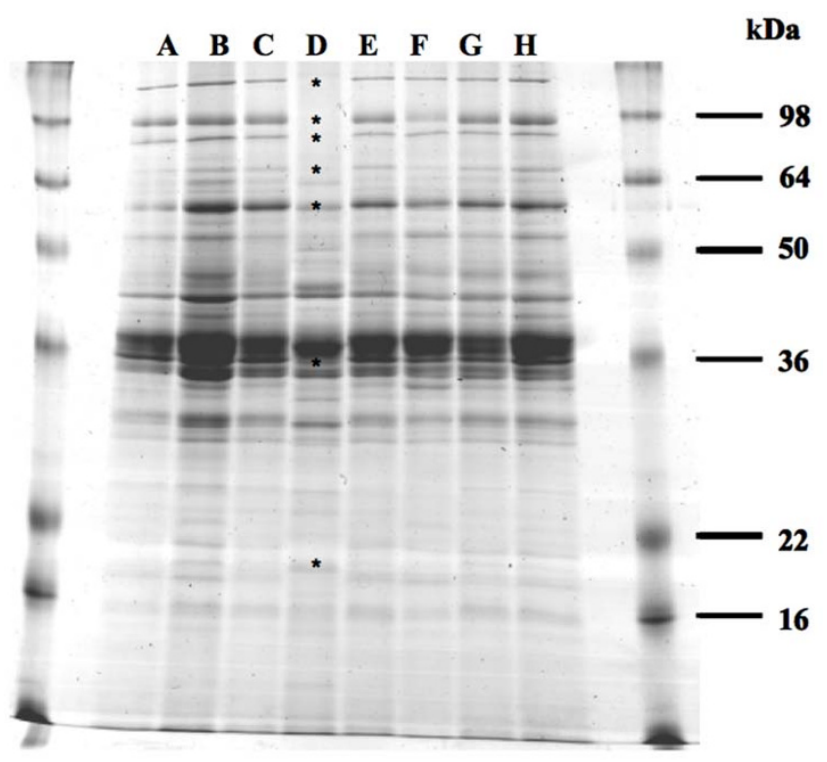

Figure 5

Culture supernatant proteins from extracellular protein secretion system mutants. Cells were grown in $Y$ mannitol medium for 4 days. Proteins were precipitated with trichloroacetic acid. A, R. I. bv. viciae 384I wild type; B, toaD mutant; C, tobD mutant; $D$, prsD mutant; $E$, virB6 mutant; $F$, autA mutant; $\mathrm{G}$, aut $B$ mutant; $\mathrm{H}$, aut $\mathrm{C}$ mutant. Protein bands missing in the lane representing the prs $D$ mutant are marked (*).

unless the strain also carried a mutation in prs $D$, in which cased the same changes as in a prs $D$ single mutant were observed. A mutation in bltD similarly had no observed effect on the profile of proteins isolated from the culture supernatant (data not shown).

Although the prs $D$ mutant differed from the wild type in culture supernatant protein profile (Fig. 5), this only accounted for seven of the many culture supernatant protein bands observed by SDS-PAGE. Most of these bands were also observed in periplasmic fractions of wild type $R$. $l$. bv. viciae 3841 , and many were indeed very abundant in this fraction, suggesting that these proteins might have reached the culture supernatant through unspecific leakage. Nevertheless, three protein bands remained which were exclusive to the culture supernatant. To identify these other proteins, bands 7, 11 and 12 were excised from the gel for MALDI-ToF MS analysis. Select bands present in both the culture supernatant and the periplasmic fraction were also excised from the gel to confirm their periplasmic origin. Table 2 and Figure 6 list 23 different proteins (including all seven bands missing from the supernatant of the prsD mutant) that were identified from the culture supernatant. Of these, proteins RL0718, RL0720 and RL0728 (Table 2) are predicted to be extracellular compo- 
Table 2: Culture supernatant proteins from R. I. bv. viciae 384 I were identified by MALDI-ToF MS.

\begin{tabular}{|c|c|c|c|c|c|c|}
\hline Band & $\begin{array}{l}\text { Apparent } \\
\text { weight } \\
\text { [kDa] }\end{array}$ & $\begin{array}{c}\text { Top MOWSE } \\
\text { score }\end{array}$ & $\begin{array}{c}\text { Number of } \\
\text { matched } \\
\text { fragments }\end{array}$ & $\begin{array}{l}\text { Predicted } \\
\text { protein }\end{array}$ & $\begin{array}{c}\text { Theoretical } \\
\text { weight }[\mathrm{kDa}]\end{array}$ & Predicted function \\
\hline$* 1$ & 89.1 & 205 & 18 & RL296I & 95.0. & cadherin-like protein \\
\hline$* 2$ & 59.2 & 165 & 15 & pRL90I40 & 79.0 & parallel beta-helix repeat protein \\
\hline$* 3$ & 57.7 & 113 & 15 & PRLI00309 & 60.7 & cadherin-like protein \\
\hline$* 4$ & 52.2 & 78 & 8 & RL24I2 & 64.6 & glycosyl hydrolase \\
\hline 5 & 50.2 & 243 & 20 & RL465I & 63.7 & dipeptide-binding protein \\
\hline $6 a$ & 46.5 & 55 & 7 & RL0778 & 58.8 & dipeptide-binding protein \\
\hline$* 6 \mathrm{~b}$ & 46.5 & 195 & 16 & RL3024 & 51.6 & PlyB \\
\hline 7 & 41.5 & 101 & 10 & RL0728 & 44.4 & flagellar hook \\
\hline 8 & 38.5 & 174 & 14 & RL4218 & 47.6 & sorbitol-binding protein \\
\hline 9 & 37.5 & 76 & 8 & RL3329 & 43.4 & membrane bound lytic tranglycosylase \\
\hline 10 & 35.6 & 77 & 7 & RL3745 & 38.9 & Leu/lle/Val-binding protein $(\mathrm{BraC})$ \\
\hline Ila & 34.1 & 60 & 6 & RL0720 & 33.6 & flagellin \\
\hline $\mathrm{IIb}$ & 34.1 & 96 & 9 & RL2375 & 38.9 & basic membrane lipoprotein \\
\hline$* 12 a$ & 29.8 & 58 & 5 & PRLI0045I & 24.9 & RapA2 \\
\hline $12 b$ & 29.8 & 60 & 6 & RL0I96 & 35.0 . & basic membrane lipoprotein \\
\hline $12 c$ & 29.8 & $44(53)$ & 5 & RL0489 & 35.4 & sugar-binding protein \\
\hline $12 \mathrm{~d}$ & 29.8 & $36(5 \mathrm{I})$ & 4 & RL07। 8 & 31.0. & flagellin \\
\hline 13 & 27.7 & 129 & 10 & RL05 I 8 & 39.4 & ribose-binding protein \\
\hline 14 & 25.0 . & 113 & 9 & RL2753 & 27.9 & arginine/ornithine-binding protein \\
\hline 15 & 20.4 & 57 & 5 & RLI369 & 24.5 & pentapeptide repeat protein \\
\hline 16 & 17.1 & 85 & 6 & RL2404 & 20.5 & peptidyl prolyl cis-trans isomerase \\
\hline$* 17$ & 16.3 & 83 & 6 & RLI580 & 15.3 & nucleoside diphosphate kinase \\
\hline 18 & 16.0 & 70 & 5 & RL2697 & 19.5 & $\operatorname{COG} 3184$ \\
\hline
\end{tabular}

The protein bands labelled in Fig. 6. were cut out from the gel and digested with trypsin. The masses of the tryptic digest were identified by MALDI-ToF MS and searched against a $R$. l. bv. viciae $384 \mathrm{I}$ genome database. Band \#, protein band as labelled in Fig. 6., Band from which more than one protein was identified are indicated (e.g. 6a, 6b). Apparent weight, molecular weight of the proteins in the given band as estimated from the electrophoretic mobility. Top MOWSE score, statistical score calculated by the MASCOT program for the R. l. bv. viciae $384 \mathrm{I}$ indicated in column 'predicted protein', scores above 50 indicate $>95 \%$ confidence. Number of matched fragments, number of fragment masses which could be assigned to the predicted protein. Predicted protein, proteins scoring more than $\mathbf{5 0}$ as MOWSE score. Theoretical weight, calculated molecular weight of the indicated proteins. Scores obtained after refining search parameters are shown in brackets. An asterisk indicates PrsDE-dependence.

nents of the flagellum and expected to be present in the culture supernatant [74-76]. Out of the 23 identified supernatant proteins (Table 2), 13 were predicted to be periplasmic by the SignalP 3.0 software [66] (Table 3). The distinction between signal peptide proteins and leaderless proteins is very clear, with proteins either having a signal peptide probability of 0.999 or better or less than 0.033 . The signal peptides are predicted to be between 20 and 32 amino acid residues in length with probabilities between 0.803 and 1.000. One of the predicted signal peptide proteins (RL0518) is also predicted to be a TAT substrate by the TATP 1.0 [77], but not by the TATFIND [78] algorithm. The predicted signal peptide of RL0518 carries a twin-arginine motif, and the surrounding residues also suggest a TAT leader peptide. The absence of this protein could not be confirmed in the culture supernatant of the tatC mutant A1052 (Fig. 4) this could either be due to the abundance of other proteins in the culture supernatant masking its absence or the possibility that it is not a TAT substrate. Five of the supernatant proteins were pre- dicted to be periplasmic substrate-binding components of $\mathrm{ABC}$ uptake transporters, two each were basic membrane proteins or conserved proteins of unknown function and one was predicted to be peptidyl-prolyl cis-trans isomerase. None had similarity to any known extracellular proteins from other bacteria. Table 3 lists all proteins identified in the culture supernatant and gives their predicted function and likely secretion system.

\section{Discussion}

Type I protein secretion in R.I. bv. viciae 384 I

The only Type I secretion systems studied in rhizobia so far have been the PrsDE system $[12,13,62]$ and systems dedicated to the export of bacteriocin $[79,80]$. This study reports the presence of a total of four predicted Type I secretion systems in R.l. bv. viciae 3841 , encoded by the prsDE, toaDE, tobDE and bltDE genes. Of these, the prsDE-encoded system has been characterised previously $[12,13,62]$ and is conserved in $S$. meliloti [15], R.l. bv. trifolii [81], R. etli and A. tumefaciens. Of the fourteen predicted Type I substrates identified in 


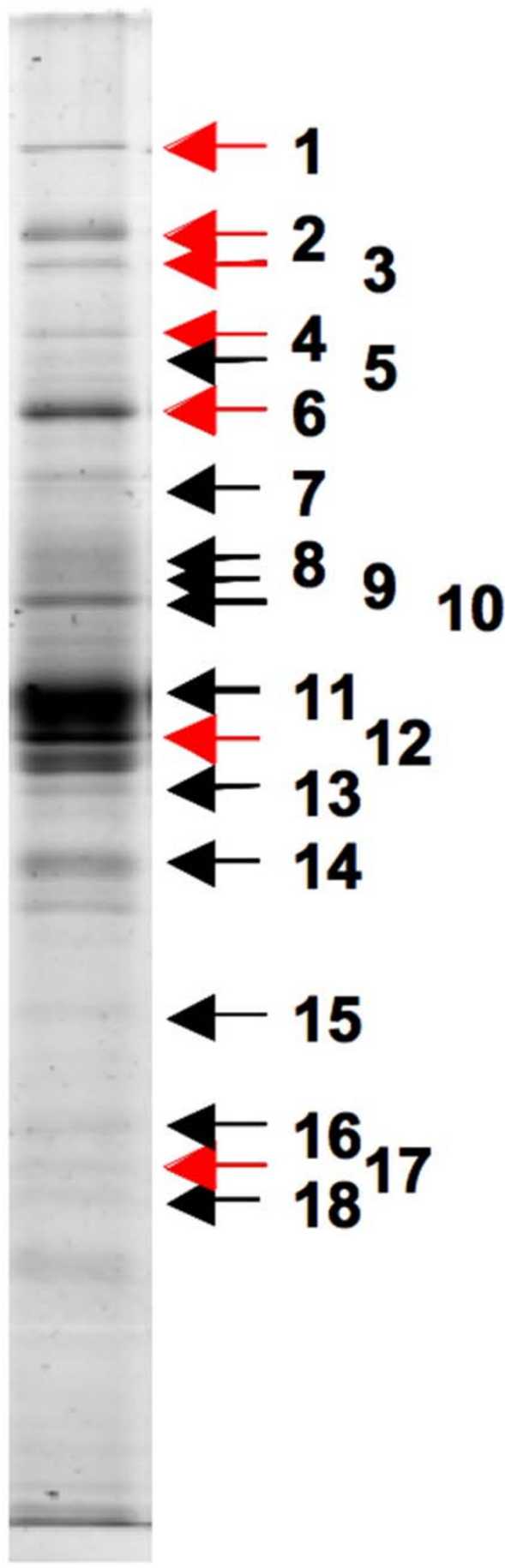

Figure 6

Protein bands submitted to MALDI-ToF MS analysis. Supernatant proteins were separated by SDS-PAGE and stained with colloidal Coomassie G. The indicated protein bands present in the wild type were excised and analysed by MALDI-ToF MS fingerprinting. Protein band missing in the culture supernatant of the prsD mutant (A898) are indicated by red arrows.
R.l. bv. viciae 3841, seven (NodO, PlyA, PlyB, PlyC, RapA2, RapB and RapC) were already known or predicted to be secreted by the PrsDE system based on previous work $[12,13,62,82]$. The other seven predicted Type I substrates were previously unknown; we demonstrated that four of these (RL2412, RL2961, pRL90140 and pRL100307) were secreted in a prsD-dependent manner, while another (RL0790) was subsequently shown to be secreted in complex (TY) growth medium in a prsDdependent manner (A. Edwards and J. A Downie unpublished data). In addition to these predicted Type I substrates, we found that the presence of RL1580 (a predicted nucleoside diphosphate kinase) in the growth medium requires prs $D$. This suggests that the PrsDE system secretes at least thirteen proteins encoded by genes in diverse regions of the genome. This is a much broader specificity than typically observed with Type I secretion systems in other bacteria, where the secretion system is usually limited to the secretion of only one or a narrow range of closely-related substrates [83,84].

A role for Type I secretion in the symbiosis has been shown previously, since the nodulation signalling protein NodO is secreted via the PrsDE system, $[11,12]$. In addition, prsD mutants of R.l. bv viciae strain A34 and R.l. bv. trifolii strain TA1 form nodules that are infected but do not fix nitrogen $[12,81]$. This is not the case with R.l. bv viciae strain 3841 and the reason for the difference is not known, although a prsD mutant of $S$. meliloti also forms nitrogen-fixing nodules [15]. Although the PrsDE secretion system in R.l. bv. viciae 3841 is not essential for nodulation, the proteins secreted by this system could nevertheless have an auxiliary function in nodulation as has already been demonstrated for NodO [5,6]. Several of the proteins whose secretion is prsD-dependent are predicted to be involved in surface attachment. This includes the Rhizobium adhering proteins RapA2, RapB and RapC identified previously [82], and RL2961 and pRL100309, which show similarity to eukaryotic cadherins. Cadherins promote calcium-dependent cell-cell adhesion in eukaryotic cells [63] indicating that RL2961 and pRL100309 could be involved in cellular aggregation, or attachment to roots an important part of legume infection. An extracellular calcium-binding protein of unknown sequence (rhicadhesin) has been identified as playing a role in rhizobial attachment to root hairs $[85,86]$, but it is much smaller than RL2961 or pRL100309.

Two of the PrsDE-dependent secreted proteins are the glycosyl hydrolases PlyA and PlyB, which cleave the extracellular acidic exopolysaccharide [13]. A plyA plyB double mutant retained some glycosyl hydrolase activity, indicating that other extracellular glycosyl hyrolases were present [59]. It is possible that the other two predicted glycosyl hydrolases (PlyC and RL2412) could cleave rhizobial 
Table 3: Prediction of signal peptides of proteins identified in the culture supernatant.

\begin{tabular}{|c|c|c|c|c|c|c|}
\hline Protein & $\begin{array}{c}\text { Signal } \\
\text { peptide } \\
\text { probability }\end{array}$ & $\begin{array}{c}\text { Maximum } \\
\text { cleavage site } \\
\text { probability }\end{array}$ & $\begin{array}{l}\text { Predicted } \\
\text { signal length } \\
\text { (aa) }\end{array}$ & Predicted signal peptide & $\begin{array}{l}\text { Predicted } \\
\text { secretion } \\
\text { system }\end{array}$ & Predicted function \\
\hline RL0196 & 1.000 & 0.999 & 20 & MKKSLLTLFAVAAMSTTALA & GEP & $\begin{array}{l}\text { basic membrane } \\
\text { lipoprotein }\end{array}$ \\
\hline RL0489 & 1.000 & 1.000 & 23 & MKKSVLAFGALALGVTFSAPVMA & GEP & sugar-binding protein \\
\hline RL05।8 & 1.000 & 1.000 & 32 & MSIVKSLLSRRAFTALAGAAVIATAMPAPSFA & TAT & ribose-binding protein \\
\hline RL0778 & 1.000 & 0.956 & 23 & MKKISVLLAATALISVMATSAWS & GEP & $\begin{array}{l}\text { dipeptide-binding } \\
\text { protein }\end{array}$ \\
\hline RLI369 & 0.999 & 0.803 & 25 & MAMHGSSLGLLALVLLAFPPVAARA & GEP & $\begin{array}{l}\text { pentapeptide repeat } \\
\text { protein }\end{array}$ \\
\hline RL2375 & 1.000 & 0.944 & 24 & MKKLALALAATAALVLSIGSAAEA & GEP & $\begin{array}{l}\text { basic membrane } \\
\text { lipoprotein }\end{array}$ \\
\hline RL2404 & 1.000 & 0.983 & 23 & MKLFYLAFAGVLYLASFAGDAFA & GEP & $\begin{array}{l}\text { peptidyl prolyl cis- } \\
\text { trans isomerase }\end{array}$ \\
\hline RL2697 & 0.999 & 0.933 & 28 & MMNIAGLGRLAAATVVLSGLAFGSAVKA & GEP & COG3I84 \\
\hline RL2753 & 1.000 & 1.000 & 25 & MLNSTRIFAAASIAAMSLFAGSAMA & GEP & $\begin{array}{l}\text { arginine/ornithine- } \\
\text { binding protein }\end{array}$ \\
\hline RL3329 & 1.000 & 0.975 & 25 & MHRSLASCSALALLFALALAGGAAA & GEP & $\begin{array}{c}\text { membrane bound lytic } \\
\text { tranglycosylase }\end{array}$ \\
\hline RL3745 & 1.000 & 0.999 & 23 & MKKSLLSAVALTAMVAFSGNAWA & GEP & $\begin{array}{l}\text { Leu/lle/ } / \text { al-binding } \\
\text { protein }(\mathrm{BraC})\end{array}$ \\
\hline RL4218 & 1.000 & 0.998 & 22 & MTLRTFLLGACSALAFAGMASA & GEP & $\begin{array}{l}\text { sorbitol-binding } \\
\text { protein }\end{array}$ \\
\hline RL465I & 1.000 & 1.000 & 29 & MTKLNRNFRMLSAGAALSLLMMAAPSAFA & GEP & $\begin{array}{l}\text { dipeptide-binding } \\
\text { protein }\end{array}$ \\
\hline pRL90I40 & 0.000 & 0.000 & - & - & PrsDE & $\begin{array}{l}\text { parallel beta-helix } \\
\text { repeat protein }\end{array}$ \\
\hline pRLI00309 & 0.000 & 0.000 & - & - & PrsDE & cadherin-like protein \\
\hline PRLI0045I & 0.000 & 0.000 & - & - & PrsDE & RapA2 \\
\hline RLI580 & 0.000 & 0.000 & - & - & PrsDE & $\begin{array}{c}\text { nucleoside } \\
\text { diphosphate kinase }\end{array}$ \\
\hline RL24I 2 & 0.000 & 0.000 & - & - & PrsDE & glycosyl hydrolase \\
\hline RL296I & 0.000 & 0.000 & - & - & PrsDE & cadherin-like protein \\
\hline RL3024 & 0.000 & 0.000 & - & - & PrsDE & PlyB \\
\hline RL07I8 & 0.002 & 0.001 & - & - & Flagellum & flagellin \\
\hline RL0720 & 0.012 & 0.005 & - & - & Flagellum & flagellin \\
\hline RL0728 & 0.032 & 0.029 & - & - & Flagellum & flagellar hook \\
\hline
\end{tabular}

Signal peptide prediction was done using the hidden Markov model of the SignalP 3.0 software [66]. Probabilities for the presence of a signal peptide and for the correct identification of the cleavage site are given. The TAT signal prediction software TATP I.0 predicts the same signal peptide length for the predicted TAT substrate RL05 I 8. The twin-arginine motif of the RL05I 8 protein is in bold. The prediction of the secretion system involved in the export of the identified proteins was based on signal peptide prediction (GEP and TAT), observed absence from the culture supernatant of the prsD mutant (PrsDE) and similarity to known proteins (Flagellum).

exopolysaccharides or could play a role in plant cell wall degradation similar to that observed previously in R. $l . b v$. trifolii [17].

RL0790 is predicted to be a secreted protease. The observation that it was present in complex medium (containing peptone), but not in minimal medium, suggests it may be induced if the bacteria are relying on peptides for growth. This is unlikely in the rhizosphere, but infection threads and senescent nodules are environments rich in proteins, and so it might be anticipated that RL0790 could contrib- ute to growth of bacteria in infection threads or in senescing plant cells.

Nucleoside diphosphate kinase (NDK) was not predicted to be a Type I substrate by the bioinformatics approach, but was absent from the culture supernatant of the prs $D$ mutant. Exported NDKs are not without precedent in mammalian pathogens; $P$. aeruginosa, Vibrio cholerae and Mycobacterium tuberculosis secrete NDKs [70,87-89], as do the parasitic nematodes Trichinella spiralis and Haemonchus contortus $[90,91]$. In $P$. aeruginosa, secretion of NDK 
into the culture supernatant has been shown to be dependent on the presence of the sequence DTEV near its C-terminus and it has been suggested that NDK secretion occurs via a Type I secretion system [70]. A very similar sequence (DTEI) is also present near the C-terminus of NDK from R.l. bv. viciae 3841. Extracellular ATP plays a role in macrophage apoptosis as a response to pathogen attack. In Arabidopsis thaliana, auxin and ATP are both transported by the metabolite transporter MDR1. Removal of extracellular ATP leads to FB1-induced cell death in a number of plants including legumes [92]. Extracellular NDK may possibly have an effect on modulating these responses, but as with the other PrsDEdependent secreted proteins its role is probably minor, since the prsD mutant lacking secretion of NDK does not appear to differ from the wild type in nodulation phenotype. A role for Type I secretion in the symbiosis has been shown previously because the nodulation signalling protein NodO is secreted via the PrsDE system, although this is not essential for nodulation $[5,12]$. In addition, $\operatorname{prs} D$ mutants of R.l. bv viciae strain A34 and R.l. bv. trifolii strain TA1 form nodules that are infected but do not fix nitrogen $[12,81]$. This is not the case with strain 3841 and the reason for the difference is not known, although a prs $D$ mutant of $S$. meliloti also forms nitrogen-fixing nodules

[15].

The predicted BltDE secretion system seems likely to be a bacteriocin/lantibiotic type exporter that secretes pRL90159 and pRl90161, large proteins encoded by genes upstream of the bltDE genes. Proteins similar to those encoded by bltDE are present in $R$. etli and a related system (Rzc) is involved in the export of medium bacteriocins in other rhizobia $[79,80]$ implying a possible role for pRL90159 and pRl90161 as bacteriocin-like proteins. However, the sequences of pRL90159 and pRl90161 are more similar to hypothetical proteins from non-rhizobia such as Nitrobacter spp. than to proteins from other rhizobia

The other two predicted Type I secretion systems are enigmatic because we did not identify any secreted proteins that require toaD or tobD for their secretion, even though we made double and triple mutants (with toaB, tobD and prs D) to test for redundancy of function. This could mean that we have not identified appropriate growth conditions, the resolution of the protein gels is inadequate to identify the products (too low in amount or too small), or even that these are not protein secretion systems, but possibly secrete some other component. Genes similar to toaD are present in syntenic locations in S. meliloti $(80 \%$ identity) [56] and A. tumefaciens (86\% identity) [93]. A protein from Bradyrhizobium japonicum has similarity to TobD (52\% identity). The genes surrounding the genes encoding these proteins also display similarity to those surrounding toaD and tobD in R.l. bv. viciae 3841, respectively, suggesting synteny and likely orthology. It is evident that these genes are not essential for growth or for the symbiosis with the tested host legumes pea, broad bean and vetch.

\section{The TAT secretion system is involved in nodulation}

The R. l. bv. viciae 3841 tatABC-encoded secretion system genes are as expected from related bacteria such as $A$. tumefaciens [54] and R. l. bv. viciae UPM 791 [38]. The tatC mutant exhibited phenotypes expected from previous work in A. tumefaciens and R. l. bv. viciae UPM791 in that the A. tumefaciens tatC mutant was also shown to be largely immotile, lacking flagellar proteins in the culture supernatant and the R. l. bv. viciae UPM791 tatC mutant also formed white nodules on peas and did not fix nitrogen. However, while the R. l. bv. viciae UPM791 tatC mutant only formed small nodules, the nodules formed by a $R$. l. bv. viciae 3841 tatC mutant were on average larger than those formed by the wild type. As in R. l. bv. viciae UPM791, the R. l. bv. viciae 3841 tatC mutant did not progress beyond the infection zone in the nodule, but unlike in $R$. l. bv. viciae UPM791 [38], viable bacteria could be isolated from nodules formed by the R. $l$. bv. viciae 3841 tatC mutant. The lack of growth and symbiotic nitrogen fixation in nodules could result from the inability of the tatC mutant to export to the periplasm electrontransport components required for respiration in the low oxygen environment in the nodule. Periplasmic proteins isolated from the tatC mutant and $R$. $l$. bv. viciae 3841 grown in TY medium give very similar patterns when separated by SDS-PAGE, suggesting that most TAT substrate proteins are either not expressed under the observed conditions or are expressed at such a low level that they are not visible on the SDS-PAGE gel.

Another major difference between the wild type and the tat $C$ mutant is the increased quantity of periplasmic proteins in the supernatant. A similar increased leakage of periplasmic contents into the extracellular space has been shown in tatC mutants of E. coli [94]. In this strain, outer membrane stability is compromised by the mislocalisation of two cell wall amidases, AmiA and AmiC, which are TAT substrates [95]. The AmiC protein from R. l. bv. viciae 3841 (RL1742) is also predicted to be a TAT substrate, suggesting that the increased leakiness of the outer membrane is due to the mislocalisation of this protein.

\section{Identification of proteins from the culture supernatant}

Previous studies on the extracellular proteome of rhizobia such as that by Suss et al. [96] have successfully used a proteomic approach to identify novel substrates of specific secretion systems, but have largely ignored proteins still present in the culture supernatant of the mutant studied. In this study, we show for the first time that many of 
the culture supernatant proteins identified by MALDI-TofMS are predicted to be periplasmic, most of them being similar to well known periplasmic proteins such as substrate binding proteins that are unlikely to function extracellularly. Type II protein secretion system secrete periplasmic proteins across the outer membrane in many Gram-negative bacteria, but such a system is absent from R. l. bv. viciae 3841. Bands corresponding to the predicted periplasmic proteins in the culture supernatant were also observed in periplasmic preparations, arguing against a specific secretion mechanism and for unspecific leakage. Periplasmic proteins have also been identified in the culture supernatant of $H$. pylori [74], but the mechanism of secretion, if any, was also unknown. The absence of the cytoplasmic protein RhiA suggests leakage from the periplasm rather than cell lysis as the reason for the presence of periplasmic proteins in the culture supernatant. Periplasmic proteins are found in the culture supernatant of $R$. l. bv. viciae 3841 at all stages of the cell cycle, and indeed are highly abundant during exponential growth. This indicates leakage from the periplasm during active growth, rather than cell death and lysis, as the likely origin of periplasmic proteins in the culture supernatant. Periplasmic proteins in the culture supernatant have previously been reported in $R$. leguminosarum RBL5523 [97]. The same study identified a mutant in which one of these proteins was absent from the culture supernatant and discussed the possible presence of a specific secretion system for this protein. To our knowledge, this is the only possible example of a periplasmic protein being secreted in rhizobia, and it seems to be limited to a single protein. Preliminary studies in our laboratory with an equivalent mutant in R. l. bv. viciae 3841 did not reveal any difference in extracellular protein profile.

Only one Type III-like system was found in the genome sequence of $R$. l. bv. viciae 3841, namely the flagellar biosynthetic cluster (Table 1). Although not classically regarded as a protein secretion system, the flagellar apparatus in Salmonella has also been shown to actively secrete proteins unrelated to flagellar biosynthesis [25], highlighting the possibility of secretion of non-flagellar proteins by the flagellar apparatus. It is not known whether $R$. l. bv. viciae 3841 utilises the flagellum for protein secretion as well. Three components of the flagellar apparatus were identified in the culture supernatant. All three are part of the flagellum itself, and so are directly exposed to the extracellular medium. As the flagellum is easily sheared from the bacterial surface, flagellar proteins are common components of the culture supernatant in many bacteria [74-76,96]. Type IV secretion systems are involved in nodulation in M. loti R7A in a host-specific manner [20]. In contrast, the virB6 mutant of R. $l$. bv. viciae 3841 was not affected in the nodulation process of any of the three host legumes tested in this study, showing that the putative Type IV protein secretion system in this strain is not essential for nodulation in these hosts.

\section{Conclusion}

Although secreted proteins play a major role in the infection process of plant and animal pathogens and are also involved in successful nodulation in certain rhizobia-legume interactions, the identified homologs of known secretion systems (with the exception of TAT) do not appear to be essential for nodulation of pea plants by R. $l$. bv. viciae 3841 . The results do not rule out the possibility of a novel protein secretion mechanism operating in this strain, as the presence of a large number of proteins in the culture supernatant remains unexplained. As these proteins are predicted to be periplasmic and indeed also abundant in periplasmic preparations, unspecific leakage from the periplasm could also account for these. Protein secretion in $R$. l. bv. viciae 3841 is furthermore distinct from that of many other Gram-negative bacteria in that the main pathway of protein secretion appears to be a Type I secretion system, PrsDE. This system is predicted to secrete at least 13 very dissimilar proteins of widely varied molecular weights. This is in direct contrast to the very narrow range of substrates recognised by most other Type I systems. The PrsDE system is conserved in other rhizobia and is required for nodulation in some of these, but not in R. l. bv. viciae 3841. The predicted functions of many of the PrsDE-dependent proteins are nevertheless consistent with auxiliary function in nodulation such as attachment, cell wall degradation, escape from senescent nodules or the modulation of the extracellular ATP pool.

\section{Methods \\ Media and growth conditions}

Strains of Rhizobium were grown at $28^{\circ} \mathrm{C}$ in TryptoneYeast (TY) medium [98] or Y [99] medium supplemented with succinate or mannitol as indicated in the text. Solid media contained $1 \%$ agar unless stated otherwise. Antibiotics were used at the following concentrations: ampicillin $400 \mu \mathrm{g} \mathrm{ml}^{-1}$; gentamicin $20 \mu \mathrm{g} \mathrm{ml}^{-1}$; kanamycin $\mu \mathrm{g} \mathrm{ml}^{-}$ 1; spectinomycin $400 \mu \mathrm{g} \mathrm{ml}^{-1}$; streptomycin $400 \mu \mathrm{g} \mathrm{ml}^{-1}$. PGase and glycanase activity were assayed on plates as described by Finnie et al. [12]. Motility was assayed by observing the absence or presence of swarming on $0.2 \%$ agar TY plates.

\section{Nodulation assay}

Nodulation assays on Pisum sativum cv. Frisson and Vicia $f a b a \mathrm{cv}$. The Sutton were done as described previously for peas by Beynon et al. [100]. Briefly, seeds were rinsed with $70 \%$ ethanol, surface-sterilised by treatment with $5 \%$ sodium hypochlorite for 10 minutes and germinated on agar medium in the dark. Vicia hirsuta seeds were scarified with sulphuric acid and germinated on agar slants as described by Knight et al. [101]. 


\section{Protein electrophoresis}

Discontinuous sodium dodecyl sulphate polyacrylamide gel electrophoresis (SDS-PAGE) was used to separate denatured proteins according to molecular weight [102]. The discontinuous system consisted of a stacking gel (4\% (w/v) acrylamide, $\mathrm{pH} 6.8)$ and a separating gel (12\% (w/ v) acrylamide, $\mathrm{pH} 8.8$ ). The gels were cast and run in the vertical Biorad MiniProtean II system. Samples were prepared by adding an equal volume of $2 \times$ SDS sample buffer and incubating for $10 \mathrm{~min}$ in a boiling water bath. Gels were run at $25 \mathrm{~mA}$ per gel using $50 \mathrm{mM}$ Tris/glycine $\mathrm{pH} 8.6,0.1 \%(\mathrm{w} / \mathrm{v})$ SDS as running buffer.

\section{Preparation of culture supernatant proteins}

Cells grown in $100 \mathrm{ml}$ of liquid Y mannitol medium for four days until stationary phase were pelleted by centrifugation for $45 \mathrm{~min}$ at $15,000 \times \mathrm{g}$ at $4^{\circ} \mathrm{C}$. $20 \%(\mathrm{w} / \mathrm{v})$ trichloroacetic acid (TCA) was added to the supernatant to a final concentration of $5 \%(\mathrm{w} / \mathrm{v})$. After $30 \mathrm{~min}$ incubation on ice, the supernatant proteins were pelleted by centrifugation for $1 \mathrm{~h}$ at $15,000 \times \mathrm{g}$ at $4^{\circ} \mathrm{C}$. The pellet was washed twice with $80 \%(\mathrm{v} / \mathrm{v})$ acetone, $50 \mathrm{mM}$ Tris/HCl pH 8.0 to remove residual TCA and air-dried prior to resuspension in SDS-PAGE sample buffer. Other methods to precipitate culture supernatant such as acetone precipitation, ammonium sulphate precipitation or lyophilisation of the culture supernatant were found to be ineffective for this strain due to the presence of large amounts of exopolysaccharide that were co-precipitated by these methods.

\section{Generation of mutants}

Mutants are listed in Table 4 and all except toaD and tatC were identified by PCR from an arrayed random Tn5insertion library using gene- and Tn5-specific primers. The locations of insertion of Tn5 were confirmed by DNA sequencing. Strains carrying an insertion in two of the genes of interest, tatC and toad, were not present in this random library and were therefore constructed by double homologous recombination. For the construction of a toaD mutant, a $2 \mathrm{~kb}$ fragment carrying the toa $\mathrm{D}$ gene was cloned into pJQ200SK [103] and a spectinomycin resistance cassette ligated into the unique NcoI site within toaD. This construct was then recombined into the genome by a double homologous recombination. The tatC mutant was generated using a similar approach to that used to inactivate toaD. PCR and DNA sequencing were used to verify that all insertions interrupted the gene of interest.

To avoid the problem of possible redundancy between the different members of Type I protein secretion systems, a prsD/toaD/tobD triple mutant and all double combinations were generated. To achieve this, the kanamycin resistance in the prs $D$ mutant A895 was exchanged for gentamicin resistance by homologous recombination within the Tn5 sequence using plasmid pJQ175 [104], resulting in strain A898. Gentamicin resistance from this prsD mutant (A898) and spectinomycin resistance from the toaD mutant (A913) were then transduced consecutively into the kanamycin resistant tobD mutant (A896) to produce the $p r s D / t o a D / t o b D$ triple mutant $A 912$. The double mutants toaD/prsD (A911) and tobD/prsD (A903) were constructed similarly. The mutants were checked by PCR and DNA sequencing. Although also part of a putative Type I secretion system, the BltD protein clearly belonged to a different class of proteins than the other three Type I ABC protein exporters. Therefore double or triple mutants protein exporter mutants carrying the bltD mutation were not made.

\section{Analysis of sequence data}

Nucleotide sequence data was curated and annotated using the CloneManager or Artemis software packages. Versions of BLAST [53] were used to carry out similarity searches in various databases. Sequences were aligned using ClustalX 1.8 [105], TreeView [106] was used to visualise dendrograms and phylograms. GEP signal

Table 4: Strains used in this work

\begin{tabular}{|c|c|c|}
\hline Strain & Description & Reference \\
\hline 3841 & R.I. bv. viciae wild-type $\mathrm{Str}^{R}$ & {$[108]$} \\
\hline A895 & 384 I carrying prsD::Tn5 & This study \\
\hline A896 & 3841 carrying tobD::Tn5 & This study \\
\hline A897 & 384 I carrying virB6::Tn5 & This study \\
\hline A898 & prsD::Tn5(gent): A895 containing gentamicin cassette replacing Tn5-neomycin resistance & This study \\
\hline A903 & prsD::Tn5(gent), tobD::Tn5; made by transduction of A896 with phage from A898 & This study \\
\hline A91। & prsD::Tn5(gent), toaD::spec; made by transduction of $A 898$ with phage from $A 913$ & This study \\
\hline A912 & prsD::Tn5(gent), tobD::Tn5, toaD::spec; made by transduction of $A 903$ with phage from A9/3 & This study \\
\hline A913 & 384 I carrying toaD::spec & This study \\
\hline Al010 & 384 I carrying autA::Tn5 & This study \\
\hline AlOII & 384 I carrying autB::Tn5 & This study \\
\hline $\mathrm{AlO} 12$ & 384 I carrying autC::Tn5 & This study \\
\hline Al052 & 384I carrying tatC::spec & This study \\
\hline
\end{tabular}


sequences were predicted using the programs PrediSi and SignalP 3.0, TATFIND and TATP 1.0 were used for the prediction of TAT substrates. The RL and pRL numbers refer to gene identifiers used in the genome sequence of R.l. bv. viciae strain 3841 [107].

\section{MALDI-ToF MS}

The proteins contained in the gel slices (approx. $2 \times 8$ $\mathrm{mm}$ ) were submitted to tryptic digest and MALDI ToF MS fingerprinting. The MS data were queried against a database containing the predicted $R$. l. bv. viciae 3841 protein sequences using the MASCOT software. Proteins achieving a MOWSE score of more than 51 (representing more than 95\% confidence) were regarded as positively identified. Most proteins were identified with more than $99 \%$ confidence. All MASCOT searches were carried out on the complete database without molecular weight constraints, but the theoretical molecular weights of the predicted proteins all lay within $15 \mathrm{kDa}$ of the molecular weight observed on the gel. Restricting the upper molecular weight limit adds additional data to the database search parameters and would result in even higher MOWSE scores, especially for relatively small proteins. As the molecular weight of many proteins can be estimated from an SDS-PAGE gel, this would be a legitimate constraint under the assumption that there is no major posttranslational processing. The MOWSE score for any individual proteins in a protein mixture is reduced, as many of the fragments in a mixture would remain unmatched to any single protein. For this reason, proteins identified from band 12 (which comes from a region of the gel with many closely-spaced protein bands) tend to have lower MOWSE scores than proteins matched to clear single bands. Two proteins from band 12 (RL0713 and RL0489) actually achieve MOWSE scores below the statistical cutoff at 51 . Considering their molecular weights and the fact that they clearly come from a mixed band, they were nevertheless included. Removing fragments from the positively identified proteins pRL100451 and RL0196 from the band 12 dataset lifts the MOWSE score above the cutoff. This is not the case for low scoring proteins in the other datasets.

\section{Authors' contributions}

MK performed the bioinformatic analysis, carried out the experiments and drafted the manuscript jointly with JAD, who coordinated the study. Both authors have read and approved the final manuscript.

\section{Acknowledgements}

The authors would like to thank Anne Edwards for communicating information about RL0790, Karen Wilson, Igor Galetich, Mike Naldrett for their help with MALDI-ToF MS analysis. We also thank Tracy Palmer, Alan Williams and Anne Edwards for useful discussions, Govind Chandra for his help with signal peptide prediction and Nienke Buddelmeijer for critical reading of the manuscript. This work was supported by a John Innes Foundation studentship (to MK), a grant-in-aid and in part by a response-mode grant
(PI9980) from the Biotechnology and Biological Sciences Research Council (BBSRC).

\section{References}

I. Hirsch AM, Lum MR, Downie JA: What makes the rhizobia-legume symbiosis so special? Plant Physiol 200 I, I 27(4): | 484-| 492.

2. Shaw LJ, Morris P, Hooker JE: Perception and modification of plant flavonoid signals by rhizosphere microorganisms. Environ Microbiol 2006, 8( I I ): I867-I880.

3. Perret $X$, Staehelin C, Broughton WJ: Molecular basis of symbiotic promiscuity. Microbiol Mol Biol Rev 2000, 64(I): |80-20I.

4. Cullimore JV, Ranjeva R, Bono J): Perception of lipo-chitooligosaccharidic Nod factors in legumes. Trends Plant Sci 200I, 6(I):24-30.

5. Downie JA, Surin BP: Either of two nod gene loci can complement the nodulation defect of a nod deletion mutant of Rhizobium leguminosarum bv. viciae. Mol Gen Genet 1990, 222(I):8I-86.

6. van Rhijn P, Luyten E, Vlassak K, Vanderleyden J: Isolation and characterization of a pSym locus of Rhizobium sp. BR8I6 that extends nodulation ability of narrow host range Phaseolus vulgaris symbionts to Leucaena leucocephala. Mol Plant Microbe Interact 1996, 9(I):74-77.

7. Dinh T, Paulsen IT, Saier MH Jr: A family of extracytoplasmic proteins that allow transport of large molecules across the outer membranes of gram-negative bacteria. J Bacteriol 1994, I 76(13):3825-3831.

8. Koronakis V, Eswaran J, Hughes C: Structure and function of TolC: the bacterial exit duct for proteins and drugs. Annu Rev Biochem 2004, 73:467-489.

9. Baumann U: Crystal structure of the $\mathbf{5 0} \mathbf{~ k D a}$ metallo protease from Serratia marcescens. J Mol Biol I994, 242(3):244-25I.

10. Baumann U, Wu S, Flaherty KM, McKay DB: Three-dimensional structure of the alkaline protease of Pseudomonas aeruginosa: a two-domain protein with a calcium binding parallel beta roll motif. EMBO J 1993, I 2(9):3357-3364.

II. Economou A, Hamilton WD, Johnston AW, Downie JA: The Rhizobium nodulation gene nod $\mathrm{O}$ encodes a $\mathrm{Ca}^{2+}$-binding protein that is exported without $\mathbf{N}$-terminal cleavage and is homologous to haemolysin and related proteins. EMBO J 1990, 9(2):349-354.

12. Finnie C, Hartley NM, Findlay KC, Downie JA: The Rhizobium leguminosarum prsDE genes are required for secretion of several proteins, some of which influence nodulation, symbiotic nitrogen fixation and exopolysaccharide modification. Mol Microbiol 1997, 25(I): I35-146.

13. Finnie C, Zorreguieta A, Hartley NM, Downie JA: Characterization of Rhizobium leguminosarum exopolysaccharide glycanases that are secreted via a Type I exporter and have a novel heptapeptide repeat motif. J Bacteriol I998, I80(7): I69|-I699.

14. Scheu AK, Economou A, Hong GF, Ghelani S, Johnston AW, Downie JA: Secretion of the Rhizobium leguminosarum nodulation protein NodO by haemolysin-type systems. Mol Microbiol 1992, 6(2):23I-238.

15. York GM, Walker GC: The Rhizobium meliloti exoK gene and prsD/prsE/exsH genes are components of independent degradative pathways which contribute to production of lowmolecular-weight succinoglycan. Mol Microbiol I997, 25(I): I I7-I34.

16. York GM, Walker GC: The succinyl and acetyl modifications of succinoglycan influence susceptibility of succinoglycan to cleavage by the Rhizobium meliloti glycanases ExoK and ExsH. J Bacteriol 1998, I 80( I 6):4184-4191.

17. Mateos PF, Jimenez-Zurdo Jl, Chen J, Squartini AS, Haack SK, Martinez-Molina E, Hubbell DH, Dazzo FB: Cell-associated pectinolytic and cellulolytic enzymes in Rhizobium leguminosarum biovar trifolii. Appl Environ Microbiol 1992, 58(6): I816-1822.

18. Palomares A, Montoya E, Olivares J: Quality and rate of extracellular polysaccharides produced by Rhizobium meliloti and their inducing effect on polygalacturonase production in legume roots as derived from the presence of extrachromosomal DNA. Microbios 1978, 22(87):7-13.

19. Bartsev AV, Boukli NM, Deakin WJ, Staehelin C, Broughton WJ: Purification and phosphorylation of the effector protein 
NopL from Rhizobium sp. NGR234. FEBS Lett 2003, 554(3):27I-274.

20. Hubber A, Vergunst AC, Sullivan JT, Hooykaas PJ, Ronson CW: Symbiotic phenotypes and translocated effector proteins of the Mesorhizobium loti strain R7A VirB/D4 type IV secretion system. Mol Microbiol 2004, 54(2):56I-574.

21. Marie C, Deakin WJ, Viprey V, Kopcinska J, Golinowski W, Krishnan HB, Perret X, Broughton WJ: Characterization of Nops, nodulation outer proteins, secreted via the type III secretion system of NGR234. Mol Plant Microbe Interact 2003, I6(9):743-75I.

22. Skorpil P, Saad MM, Boukli NM, Kobayashi H, Ares-Orpel F, Broughton W], Deakin W]: NopP, a phosphorylated effector of Rhizobium sp. strain NGR234, is a major determinant of nodulation of the tropical legumes Flemingia congesta and Tephrosia vogelii. Mol Microbiol 2005, 57(5): | 304-|3|7.

23. Macnab RM: The bacterial flagellum: reversible rotary propellor and type III export apparatus. I Bacteriol 1999 , I8I(23):7|49-7|53.

24. Nguyen L, Paulsen IT, Tchieu J, Hueck CJ, Saier MH Jr: Phylogenetic analyses of the constituents of Type III protein secretion systems. J Mol Microbiol Biotechnol 2000, 2(2): 125-I44.

25. Young GM, Schmiel DH, Miller VL: A new pathway for the secretion of virulence factors by bacteria: the flagellar export apparatus functions as a protein-secretion system. Proc Natl Acad Sci USA 1999, 96(I I):6456-646I.

26. Cornelis GR, Van Gijsegem F: Assembly and function of type III secretory systems. Annu Rev Microbiol 2000, 54:735-774.

27. Ausmees N, Kobayashi H, Deakin WJ, Marie C, Krishnan HB, Broughton W], Perret X: Characterization of NopP, a type III secreted effector of Rhizobium sp. strain NGR234. J Bacteriol 2004, I 86( (14):4774-4780.

28. Saad MM, Kobayashi H, Marie C, Brown IR, Mansfield JW, Broughton WJ, Deakin WJ: NopB, a type III secreted protein of Rhizobium sp. strain NGR234, is associated with pilus-like surface appendages. J Bacteriol 2005, I87(3): I I73-II8I.

29. Viprey V, Del Greco A, Golinowski W, Broughton WJ, Perret X: Symbiotic implications of type III protein secretion machinery in Rhizobium. Mol Microbiol 1998, 28(6): I38I-1389.

30. Vergunst AC, Schrammeijer B, den Dulk-Ras A, de Vlaam CM, Regensburg-Tuink TJ, Hooykaas PJ: VirB/D4-dependent protein translocation from Agrobacterium into plant cells. Science 2000, 290(5493):979-982.

31. Rodrigue A, Chanal A, Beck K, Muller M, Wu LF: Co-translocation of a periplasmic enzyme complex by a hitchhiker mechanism through the bacterial Tat pathway. I Biol Chem 1999 , 274(19): I 3223-13228.

32. Rose RW, Bruser T, Kissinger JC, Pohlschroder M: Adaptation of protein secretion to extremely high-salt conditions by extensive use of the twin-arginine translocation pathway. Mol Microbiol 2002, 45(4):943-950.

33. Berks BC, Palmer T, Sargent F: The Tat protein translocation pathway and its role in microbial physiology. Adv Microb Physiol 2003, 47: 187-254

34. Hynds PJ, Robinson D, Robinson C: The sec-independent twinarginine translocation system can transport both tightly folded and malfolded proteins across the thylakoid membrane. J Biol Chem 1998, 273(52):34868-34874.

35. Thomas JD, Daniel RA, Errington J, Robinson C: Export of active green fluorescent protein to the periplasm by the twinarginine translocase (Tat) pathway in Escherichia coli. Mol Microbiol 200I, 39(I):47-53

36. DeLisa MP, Tullman D, Georgiou G: Folding quality control in the export of proteins by the bacterial twin-arginine translocation pathway. Proc Natl Acad Sci USA 2003, I00(10):61 I 5-6120.

37. Stanley NR, Palmer T, Berks BC: The twin arginine consensus motif of Tat signal peptides is involved in Sec-independent protein targeting in Escherichia coli. I Biol Chem 2000, 275(16): II59|-II596.

38. Meloni S, Rey L, Sidler S, Imperial J, Ruiz-Argueso T, Palacios JM: The twin-arginine translocation (Tat) system is essential for Rhizobium-legume symbiosis. Mol Microbiol 2003, 48(5): I I $95-1207$

39. Paetzel M, Dalbey RE, Strynadka NC: The structure and mechanism of bacterial type I signal peptidases. A novel antibiotic target. Pharmacol Ther 2000, 87(I):27-49.
40. Watanabe M, Blobel G: High-affinity binding of Escherichia coli SecB to the signal sequence region of a presecretory protein. Proc Natl Acad Sci USA 1995, 92(22): $10133-10136$.

4I. Breyton C, Haase W, Rapoport TA, Kuhlbrandt W, Collinson I: Three-dimensional structure of the bacterial protein-translocation complex SecYEG. Nature 2002, 4l 8(6898):662-665.

42. Economou A, Wickner W: SecA promotes preprotein translocation by undergoing ATP-driven cycles of membrane insertion and deinsertion. Cell 1994, 78(5):835-843.

43. Wickner W, Driessen AJ, Hartl FU: The enzymology of protein translocation across the Escherichia coli plasma membrane. Annu Rev Biochem 1991, 60:101-124.

44. Pugsley AP: The complete general secretory pathway in gramnegative bacteria. Microbiol Rev 1993, 57(I):50-108.

45. Voulhoux R, Lazdunski A, Filloux A: Colicin A hybrids: a genetic tool for selection of Type II secretion-proficient Pseudomonas strains. $E M B O \operatorname{Rep} 2001,2(1): 49-54$.

46. Sandkvist M: Biology of Type II secretion. Mol Microbiol 200I, 40(2):27I-283

47. Henderson IR, Navarro-Garcia F, Nataro JP: The great escape: structure and function of the autotransporter proteins. Trends Microbiol 1998, 6(9):370-378.

48. Henderson IR, Navarro-Garcia F, Desvaux M, Fernandez RC Ala'Aldeen D: Type $\mathbf{V}$ protein secretion pathway: the autotransporter story. Microbiol Mol Biol Rev 2004, 68(4):692-744.

49. Henderson IR, Cappello R, Nataro JP: Autotransporter proteins, evolution and redefining protein secretion. Trends Microbio 2000, 8( I 2):529-532.

50. Jacob-Dubuisson F, Locht C, Antoine R: Two-partner secretion in Gram-negative bacteria: a thrifty, specific pathway for large virulence proteins. Mol Microbiol 200I, 40(2):306-3I3.

5I. Ajouz B, Berrier C, Garrigues A, Besnard M, Ghazi A: Release of thioredoxin via the mechanosensitive channel MscL during osmotic downshock of Escherichia coli cells. J Biol Chem 1998, 273(4I):26670-26674.

52. Beacham IR: Periplasmic enzymes in gram-negative bacteria. Int J Biochem 1979, I O(I I):877-883.

53. Altschul SF, Gish W, Miller W, Myers EW, Lipman DJ: Basic local alignment search tool. I Mol Biol 1990, 2I 5(3):403-4I0.

54. Ding Z, Christie PJ: Agrobacterium tumefaciens twin-argininedependent translocation is important for virulence, flagellation, and chemotaxis but not Type IV secretion. I Bacteriol 2003, 185(3):760-771.

55. Gonzalez V Santamaria RI, Bustos $P$, Hernandez-Gonzalez I, Medrano-Soto A, Moreno-Hagelsieb G, Janga SC, Ramirez MA, jimenez-Jacinto V, Collado-Vides J, et al.: The partitioned Rhizobium etli genome: genetic and metabolic redundancy in seven interacting replicons. Proc Natl Acad Sci USA 2006, I 03( I0):3834-3839.

56. Galibert F, Finan TM, Long SR, Puhler A, Abola P, Ampe F, BarloyHubler F, Barnett MJ, Becker A, Boistard P, et al.: The composite genome of the legume symbiont Sinorhizobium meliloti. Science 200I, 293(5530):668-672.

57. Linton KJ, Higgins CF: The Escherichia coli ATP-binding cassette (ABC) proteins. Mol Microbiol 1998, 28(I):5-I3.

58. Hyde SC, Emsley P, Hartshorn MJ, Mimmack MM, Gileadi U, Pearce SR, Gallagher MP, Gill DR, Hubbard RE, Higgins CF: Structural model of ATP-binding proteins associated with cystic fibrosis, multidrug resistance and bacterial transport. Nature 1990, 346(6282):362-365.

59. Zorreguieta A, Finnie C, Downie JA: Extracellular glycanases of Rhizobium leguminosarum are activated on the cell surface by an exopolysaccharide-related component. J Bacteriol 2000, I 82(5): $|304-13| 2$

60. Delepelaire $P$ : Type I secretion in gram-negative bacteria. Biochim Biophys Acta 2004, 1694(I-3): |49-161.

61. Sonnhammer EL, Durbin R: A dot-matrix program with dynamic threshold control suited for genomic DNA and protein sequence analysis. Gene 1995, 167(I-2): GCI-10.

62. Russo DM, Williams A, Edwards A, Posadas DM, Finnie C, Dankert M, Downie JA, Zorreguieta A: Proteins exported via the PrsDPrsE type I secretion system and the acidic exopolysaccharide are involved in biofilm formation by Rhizobium leguminosarum. J Bacteriol 2006, I 88( I 2):4474-4486. 
63. Tanoue T, Takeichi M: New insights into Fat cadherins. J Cell Sci 2005, I I 8(I I):2347-2353.

64. Sijbrandi R, Urbanus ML, ten Hagen-Jongman CM, Bernstein HD, Oudega B, Otto BR, Luirink J: Signal recognition particle (SRP) mediated targeting and Sec-dependent translocation of an extracellular Escherichia coli protein. J Biol Chem 2003, 278(7):4654-4659.

65. Christie PJ: Agrobacterium tumefaciens T-complex transport apparatus: a paradigm for a new family of multifunctional transporters in eubacteria. J Bacteriol 1997, 179( ( 0):3085-3094.

66. Bendtsen JD, Nielsen H, von Heijne G, Brunak S: Improved prediction of signal peptides: SignalP 3.0. I Mol Biol 2004, 340(4):783-795.

67. Veereshlingam H, Haynes JG, Penmetsa RV, Cook DR, Sherrier DJ, Dickstein R: nip, a symbiotic Medicago truncatula mutant that forms root nodules with aberrant infection threads and plant defense-like response. Plant Physiol 2004, I 36(3):3692-3702.

68. Banerjee S, Fraenkel DG: Glucose-6-phosphate dehydrogenase from Escherichia coli and from a "high-level" mutant. J Bacteriol I 972, II O(I): I55-160.

69. Chakrabarty AM: Nucleoside diphosphate kinase: role in bacterial growth, virulence, cell signalling and polysaccharide synthesis. Mol Microbiol 1998, 28(5):875-882.

70. Kamath S, Chen ML, Chakrabarty AM: Secretion of nucleoside diphosphate kinase by mucoid Pseudomonas aeruginosa $882 \mathrm{I}$ : involvement of a carboxy-terminal motif in secretion. J Bacteriol 2000, I82(I3):3826-383I.

7I. Cubo MT, Economou A, Murphy G, Johnston AW, Downie JA: Molecular characterization and regulation of the rhizosphere-expressed genes rhiABCR that can influence nodulation by Rhizobium leguminosarum biovar viciae. J Bacteriol I992, I 74(I 2):4026-4035

72. Economou A, Hawkins FK, Downie JA, Johnston AW: Transcription of rhiA, a gene on a Rhizobium leguminosarum bv. viciae Sym plasmid, requires rhiR and is repressed by flavanoids that induce nod genes. Mol Microbiol 1989, 3(I):87-93.

73. Dibb NJ, Downie JA, Brewin NJ: Identification of a rhizosphere protein encoded by the symbiotic plasmid of Rhizobium leguminosarum. | Bacteriol | 984, I 58(2):62 I-627.

74. Bumann D, Aksu S, Wendland M, Janek K, Zimny-Arndt U, Sabarth N, Meyer TF, Jungblut PR: Proteome analysis of secreted proteins of the gastric pathogen Helicobacter pylori. Infect Immun 2002, 70(7):3396-3403.

75. Kazemi-Pour N, Condemine G, Hugouvieux-Cotte-Pattat N: The secretome of the plant pathogenic bacterium Erwinia chrysanthemi. Proteomics 2004, 4(10):3 I77-3I86.

76. Komoriya K, Shibano N, Higano T, Azuma N, Yamaguchi S, Aizawa SI: Flagellar proteins and type III-exported virulence factors are the predominant proteins secreted into the culture media of Salmonella typhimurium. Mol Microbiol 1999, 34(4):767-779.

77. Bendtsen JD, Nielsen H, Widdick D, Palmer T, Brunak S: Prediction of twin-arginine signal peptides. BMC Bioinformatics 2005, 6: 167.

78. Dilks K, Rose RW, Hartmann E, Pohlschroder M: Prokaryotic utilization of the twin-arginine translocation pathway: a genomic survey. J Bacteriol 2003, I85(4): | 478-| 483.

79. Oresnik II, Twelker S, Hynes MF. Cloning and characterization of a Rhizobium leguminosarum gene encoding a bacteriocin with similarities to RTX toxins. Appl Environ Microbiol 1999 65(7):2833-2840.

80. Venter AP, Twelker S, Oresnik IJ, Hynes MF: Analysis of the genetic region encoding a novel rhizobiocin from Rhizobium leguminosarum bv. viciae strain 306. Can J Microbiol 200I, 47(6):495-502.

81. Krol J, Skorupska A: Identification of genes in Rhizobium leguminosarum bv. trifolii whose products are homologues to a family of ATP-binding proteins. Microbiology 1997, I43(Pt 4):1389-1394.

82. Ausmees N, Jacobsson K, Lindberg M: A unipolarly located, cellsurface-associated agglutinin, RapA, belongs to a family of Rhizobium-adhering proteins (Rap) in Rhizobium leguminosarum bv. trifolii. Microbiology 2001, I 47(Pt 3):549-559.

83. Binet R, Letoffe S, Ghigo JM, Delepelaire P, Wandersman C: Protein secretion by Gram-negative bacterial ABC exporters - a review. Gene 1997, 192(I):7-II.
84. Omori K, Idei A: Gram-negative bacterial ATP-binding cassette protein exporter family and diverse secretory proteins. $J$ Biosci Bioeng 2003, 95(I): I-12.

85. Smit G, Kijne JW, Lugtenberg B]: Involvement of both cellulose fibrils and a $\mathrm{Ca}^{2+}$-dependent adhesin in the attachment of Rhizobium leguminosarum to pea root hair tips. J Bacteriol I987, I 69(9):4294-430I.

86. Smit G, Swart S, Lugtenberg BJ, Kijne JW: Molecular mechanisms of attachment of Rhizobium bacteria to plant roots. Mol Microbiol I992, 6(20):2897-2903.

87. Chopra P, Singh A, Koul A, Ramachandran S, Drlica K, Tyagi AK, Singh Y: Cytotoxic activity of nucleoside diphosphate kinase secreted from Mycobacterium tuberculosis. Eur J Biochem 2003, 270(4):625-634.

88. Punj V, Zaborina O, Dhiman N, Falzari K, Bagdasarian M, Chakrabarty AM: Phagocytic cell killing mediated by secreted cytotoxic factors of Vibrio cholerae. Infect Immun 2000, 68(9):4930-4937.

89. Zaborina O, Dhiman N, Ling Chen M, Kostal J, Holder IA, Chakrabarty AM: Secreted products of a nonmucoid Pseudomonas aeruginosa strain induce two modes of macrophage killing: external-ATP-dependent, P2Z-receptor-mediated necrosis and ATP-independent, caspase-mediated apoptosis. Microbiology 2000, I 46(Pt I 0):252I-2530.

90. Gounaris K, Thomas S, Najarro P, Selkirk ME: Secreted variant of nucleoside diphosphate kinase from the intracellular parasitic nematode Trichinella spiralis. Infect Immun 200I, 69(6):3658-3662

91. Yatsuda AP, Krijgsveld J, Cornelissen AW, Heck AJ, de Vries E: Comprehensive analysis of the secreted proteins of the parasite Haemonchus contortus reveals extensive sequence variation and differential immune recognition. I Biol Chem 2003, 278(19): 1694I-1695I.

92. Chivasa S, Ndimba BK, Simon WJ, Lindsey K, Slabas AR: Extracellular ATP functions as an endogenous external metabolite regulating plant cell viability. Plant Cell 2005, I7(I I):30I9-3034.

93. Wood DW, Setubal JC, Kaul R, Monks DE, Kitajima JP, Okura VK, Zhou Y, Chen L, Wood GE, Almeida NF Jr, et al.: The genome of the natural genetic engineer Agrobacterium tumefaciens C58. Science 200I, 294(5550):23I7-2323.

94. Stanley NR, Findlay K, Berks BC, Palmer T: Escherichia coli strains blocked in Tat-dependent protein export exhibit pleiotropic defects in the cell envelope. J Bacteriol 200I, I83(I):I39-I44.

95. Ize B, Stanley NR, Buchanan G, Palmer T: Role of the Escherichia coli Tat pathway in outer membrane integrity. Mol Microbiol 2003, 48(5): I I83-11 93.

96. Suss C, Hempel J, Zehner S, Krause A, Patschkowski T, Gottfert M: Identification of genistein-inducible and Type III-secreted proteins of Bradyrhizobium japonicum. J Biotechnol 2006, 126(I):69-77.

97. Bladergroen MR, Badelt K, Spaink HP: Infection-blocking genes of a symbiotic Rhizobium leguminosarum strain that are involved in temperature-dependent protein secretion. Mol Plant Microbe Interact 2003, 16(I):53-64.

98. Beringer JE: $\mathbf{R}$ factor transfer in Rhizobium leguminosarum. J Gen Microbiol 1974, 84(I): I 88-198.

99. Sherwood MT: Improved synthetic medium for the growth of Rhizobium. J Appl Bacteriol 1970, 33(4):708-7|3.

100. Beynon JL, Beringer JE, Johnston AW: Plasmids and host range in Rhizobium leguminosarum and Rhizobium phaseoli. J Gen Microbiol 1980, 1 20:42 I-429.

10I. Knight CD, Rossen L, Robertson JG, Wells B, Downie JA: Nodulation inhibition by Rhizobium leguminosarum multicopy nodABC genes and analysis of early stages of plant infection. | Bacteriol 1986, 166(2):552-558.

102. Laemmli UK: Cleavage of structural proteins during the assembly of the head of bacteriophage T4. Nature 1970, 227(5259):680-685.

103. Quandt J, Hynes MF: Versatile suicide vectors which allow direct selection for gene replacement in gram-negative bacteria. Gene 1993, |27(1):|5-2|.

104. Quandt J, Clark RG, Venter AP, Clark SR, Twelker S, Hynes MF: Modified RP4 and Tn5-Mob derivatives for facilitated manipulation of large plasmids in Gram-negative bacteria. Plasmid 2004, 52(I): I- I2.

105. Thompson JD, Gibson TJ, Plewniak F, Jeanmougin F, Higgins DG: The CLUSTAL_X windows interface: flexible strategies for mul- 
tiple sequence alignment aided by quality analysis tools. Nucleic Acids Res 1997, 25(24):4876-4882.

106. Page RD: TreeView: an application to display phylogenetic trees on personal computers. Comput Appl Biosci 1996, I 2(4):357-358.

107. Young JP, Crossman LC, Johnston AW, Thomson NR, Ghazoui ZF, Hull KH, Wexler M, Curson AR, Todd JD, Poole PS, et al:: The genome of Rhizobium leguminosarum has recognizable core and accessory components. Genome Biol 2006, 7(4):R34.

108. Johnston AW, Beringer JE: Identification of the Rhizobium strains in pea root nodules using genetic markers. J Gen Microbiol 1975, 87(2):343-350.

Publish with Bio Med Central and every scientist can read your work free of charge

"BioMed Central will be the most significant development for disseminating the results of biomedical research in our lifetime. "

Sir Paul Nurse, Cancer Research UK

Your research papers will be:

- available free of charge to the entire biomedical community

- peer reviewed and published immediately upon acceptance

- cited in PubMed and archived on PubMed Central

- yours - you keep the copyright 